\title{
Relation Back of Amendments Naming Previously Unnamed Defendants Under Federal Rule of Civil Procedure 15(c)
}

\author{
Rebecca S. Engrav $\dagger$
}

Normally, plaintiffs cannot amend their complaints to bring in new defendants after the statute of limitations applicable to the new defendants has run. However, in certain circumstances such an amendment will be allowed to "relate back" to the date the original complaint was filed, thus avoiding the bar of the statute of limitations. Federal Rule of Civil Procedure 15(c) governs relation back in federal court. It provides that an amendment that changes a defendant or names a new defendant will relate back when the claims against the new defendant arise out of the same transaction as the original claims, when the new defendant was not named originally because of a "mistake," and when the new defendant has notice both of the existence of the suit itself and that it was not named because of the plaintiff's mistake. The "mistake" clause has produced inconsistent results when applied to situations in which, at the time the suit was filed, the plaintiff made no factual mistake, but just did not know the identity of the correct defendant. Some courts have allowed relation back in such situations, but the majority of courts have not. This Comment argues that the language of Rule 15(c) should be changed to correct this inconsistency and to allow relation back in such situations, so long as the defendant being brought in has had notice of the suit and that it is an intended defendant.

Copyright $(2001$ California Law Review, Inc. California Law Review, Inc. (CLR) is a California nonprofit corporation. CLR and the authors are solely responsible for the content of their publications.

$+\quad$ Law Clerk to the Honorable Sidney R. Thomas, United States Court of Appeals for the Ninth Circuit, 2001-2002; Law Clerk to the Honorable David O. Carter, United States District Court for the Central District of California, 2000-2001; J.D., School of Law, University of California, Berkeley (Boalt Hall), 2000. For their assistance and advice regarding this Comment, I thank the Honorable William A. Fletcher, Julia M. Fromholz, Professor Jan Vetter, Joon-Ho Yu, and the editors and staff of the California Law Review. 


\section{INTRODUCTION}

Common sense suggests that most individuals initiating civil lawsuits are well aware of the identity of the person or company whom they wish to sue. In a few types of situations, however, plaintiffs ${ }^{1}$ initially may have a great deal of difficulty ascertaining the name or identity of the correct defendant. For example, when bringing actions against United States government agencies or entities, plaintiffs frequently sue "The United States" instead of the head of the relevant agency, or vice versa. ${ }^{2}$ In suits against business entities, the complexities of corporate structure at times unake it difficult to determine the legally responsible entity. ${ }^{3}$ Or, plaintiffs at times are completely unaware of defendants' identities at the time the alleged events occurred and cannot find out that information without the aid of formal discovery procedures. This lack of knowledge often occurs in civil rights claims brought against state police ${ }^{4}$ and correctional ${ }^{5}$ officers, although it may occur in other kinds of injury actions. ${ }^{6}$ In such cases, plaintiffs often rely on naming a fictitious "John Doe" as a defendant to preserve their clainı until such time as the correct names can be determined. ${ }^{7}$

Plaintiffs in these situations commonly seek leave to amend their complaints to add, change, or correct the names of defendants after the

1. Although claims can be brought by plaintiffs, counterclaimants, cross-claimants, or thirdparty plaintiffs, for ease of reference, this Comment uses "plaintiff" and "defendant" to refer to the party asserting a claim and the party defending against the claim. The issues diseussed apply equally to parties asserting counterclaims, cross claims, or third-party claims.

2. See, e.g., Allgeicr v. United States, 909 F.2d 869, 871 (6th Cir. 1990) (plaintiff in Federal Tort Claims Act mistakenly sued United States Post Office instead of the United States); Harris v. United States Dep't of Transp., 843 F.2d 219, 220 (5th Cir. 1988) (plaintiff in employment discrimination case mistakenly sued the Department of Transportation and the Coast Guard instead of the heads of those agencies); Cunningham v. United States, 199 F. Supp. 541, 541 (W.D. Mo. 1958) (plaintiff seeking review of denial of social security benefits mistakenly sued United States rather than Secretary of Health, Education, and Welfare).

3. See, e.g., Schiavone v. Fortune, 477 U.S. 21, 23 (1986) (plaintiff sued Fortune magazine instead of its parent company, Time, 1nc.); Sterling v. Interlake Indus. Inc., 154 F.R.D. 579, 581-82 (E.D.N.Y. 1994) (at time of filing the complaint, the plaintiff was not able to determine whether the defendant was a wholly owned subsidiary of another company and if not, which eompany was the manufacturer of the item that allegedly harmed her).

4. See, e.g., Jacobsen v. Osborne, 133 F.3d 315, 317-18 (5th Cir. 1998); Worthington v. Wilson, 8 F.3d 1253, 1254 (7th Cir. 1993); Barrow v. Wethersfield Police Dep't, 66 F.3d 466, 466 (2d Cir. 1995), amended by 74 F.3d 1366 (2d Cir. 1996); Perri v. Daggy, 776 F. Supp. 1345, 1349 (N.D. Ind. 1991).

5. See, e.g., Byrd v. Abate, 964 F. Supp. 140, 143 (S.D.N.Y. 1997).

6. See, e.g., Wilson v. United States Gov't, 23 F.3d 559, 560-61 (1st Cir. 1994) (action under Public Vessels Act and Suits in Admiralty Act); Varlaek v. SWC Caribbean, Inc., 550 F.2d 171, 174 (3d Cir. 1977) (personal injury action against restaurant); Swartz v. Gold Dust Casino, Ine., 91 F.R.D. 543,544 (D. Nev. 1981) (tort claims arising out of a fall on casino stairs).

7. While not explicitly provided for under the federal rules, Doe-type pleading does occur in federal cases. E.g., Bivens v. Six Unknown Named Agents of Fed. Bureau of Narcotics, 403 U.S. 388 (1971). Doe pleading in diversity cases presents several problems outside the scope of this Comment. 
beginning of the lawsuit. Motions to amend a pleading are governed by Federal Rule of Civil Procedure 15, which provides that parties may amend their pleadings once as a matter of course within twenty days of the original pleading, or, after twenty days, with the written consent of the adverse party or by leave of court. ${ }^{8}$ Leave is within the discretion of the trial court ${ }^{9}$ and "shall be freely given when justice so requires." When a party seeks leave to amend in order to add or change parties, the trial court must determine whether the amendment relates back to the date of the original pleading. ${ }^{11}$ An amendment that relates back will be treated as if it had been filed on the same date as the original pleading. Relation back, therefore, allows a case to proceed against a new or changed party even if the amendinent is made after the time period set forth by the statute of limitations has expired. Thus, although the plaintiff in such a situation could not file a new action against the new or changed defendant at that time, because of relation back the plaintiff may nonetheless proceed against the new or changed defendant.

Rule 15(c) provides that an amendinent relates back either when allowed by the statute of limitations law governing the underlying action ${ }^{12}$ or when three requirements are met. These requirements are (1) that the claim asserted by the amendinent arises out of the conduct, transaction, or occurrence set forth in the original pleading; (2) that the party to be brought in has received such notice of the institution of the action that the party will not be prejudiced in maintaining a defense on the merits; and (3) that the party to be brought in knew or should have known that, but for a mistake concerning the identity of the proper party, the action would have been brought against the party. ${ }^{13}$ This third requirement, that amendment is sought because of a "mistake concerning the identity of the proper party,"14 encompasses many cases in which the plaimtiff sues the wrong government entity or misidentifies the legally responsible corporate entity. However, it does not address circumstances in which the plaintiff has made no "mistake" but just does not know, and perhaps caunot easily find out, the correct defendant's identity.

In some of these situations, the intended defendant is as unaware of the suit as the plaintiff is unaware of the defendant's identity. The statute of limitations exists to protect such a defendant. However, in other situations the intended defendant has knowledge both of the suit and that the plaintiff

\footnotetext{
8. Fed. R. Civ. P. 15(a).

9. See Foman v. Davis, 371 U.S. 178, 182 (1962) (holding that grant or denial of leave to amend is within the discretion of the trial court).

10. Fed. R. Civ. P. 15(a).

11. Fed. R. Crv. P. 15(c).

12. FED. R. CIV. P. 15(c)(1).

13. FED. R. CIV. P. 15(c)(3).

14. Id.
} 
is seeking to sue the intended defendant. Such a defendant knows that the only reason it has not been sued is that the plaintiff cannot determine its name. For example, in Byrd v. Abate, ${ }^{15}$ an inmate brought a civil rights claim against various institutional defendants and a John Doe correctional officer. ${ }^{16}$ The allegations of the complaint were specific and made it clear that the plaintiff wished to sue the officer who was assigned to watch over a specific recreation room on the specific day when another inmate had attacked the plaintiff. ${ }^{17}$ The name of this officer was, as is common in such situations, uniquely within the control of the institutional defendants, as they had complete control over the prison's log books and the duty roster for the officers. ${ }^{18}$ The plaintiff, who was mentally ill, had been moved to that ward the day before the attack. ${ }^{19}$ The same attorney represented both the institutional defendants and the officer. ${ }^{20}$ Because responding to the complaint on behalf of the institutional defendants would necessarily involve obtaining prison records and making at least a cursory investigation into what had happened, which, almost without a doubt, would include determining which officers were on duty at the time of the attack, it seems nearly certain that the John Doe officer knew of the suit soon after it was filed. However, Byrd did not determine that officer's name until three months after the statute of limitations had passed. The defendants' counsel refused to provide it after repeated requests from Byrd's counsel, beginning ten months before the statute of limitations ran. ${ }^{21}$ Extending the

\footnotetext{
15. 964 F. Supp. 140 (S.D.N.Y. 1997).

16. Id. at 143 .

17. Id. at 146.

18. Id.

19. Id. at 142 .

20. Id. at 146 .

21. Id. at 143; see also infra notes 203-213 and accompanying text.

As noted, relation back can arise in any type of case, but it seems to arise most often in civil rights cases, especially those against law enforcement agencies and officers. Several reasons can be hypothesized for why this is so. Because many of those who have significant contact with law enforcement officers are poor, a disproportionately large number of the plaintiffs in such cases are poor. This lack of financial resources means both that they are unlikely to hire an attorney quickly, meaning that suits often are not filed until close to the end of the statute of limitations period, and that they quite often proceed pro se and therefore have less knowledge about statutes of limitations and methods of discovery. Plaintiffs who are incarcerated at the time they file suit have these same difficulties. Moreover, it is even harder for them to do any type of pre-filing factual investigation. In addition, unlike many other situations that give rise to litigation, such as business dealings, the participants in these cases usually do not know each other before the underlying events occur and do not introduce themselves by name. Finally, and perhaps most significantly, there is no way to find out the name of the law enforcement officer who was involved in a specific event except by asking the law enforcement agency. For security and reasons of officer safety, this type of information is not given out freely. This last reason exacerbates the impact of the other reasons, because it makes the need for immediate, competent legal representation more urgent.

In large part, the proposal advanced in this Comment would not change the outcome of most relation-back decisions. Primarily, it would make the reasoning used by courts more coherent and more consistent. It would, however, change the results of some relation-back decisions and thereby allow more cases to be heard on the merits. However, it is important to note that while allowing relation back
} 
doctrine of relation back to such situations is fair and would advance the purposes of the federal rules. ${ }^{22}$ Allowing amendments to relate back would not decrease the diligence required of plaintiffs who need to find the correct defendant, and it would eliminate the current incentive for potential defendants to fight discovery in order to put off being identified until after the statute of limitations has expired.

This Comment proposes that Rule 15(c) be modified to allow relation back for amendments seeking to add new defendants or substitute named defendants for Doe defendants, so long as the defendant to be brought in has notice that suit has been brought and that it is an intended defendant. Part I provides a brief history of relation-back doctrine and Rule 15(c), focusing on how the amendments to Rule 15 have consistently reinforced the Rules' purpose of facilitating decisions on the merits, rather than on technicalities. ${ }^{23}$ In particular, although they did not address Doe situations, both the 1966 and 1991 amendments to Rule I5 assisted plaintiffs who faced difficulties in ascertaining the identity of the correct defendant. ${ }^{24}$

Part II analyzes how courts have applied the current version of Rule 15(c) to three kinds of situations: when the plaintiff seeks leave to amend (1) to correct a misnomer, (2) to substitute a new defendant for one mistakenly identified as the chargeable party, and (3) to name an additional defendant or substitute a named defendant for a Doe defendant. The Rule's "but for a mistake" clause only conclusively handles the first of these situations, and courts have applied it to the other two in contradictory ways.

Part III argues that relation back should be available when the plaintiff seeks to add a new defendant or in Doe situations. First, extending 15(c) to include cases in which the plaintiff seeks to amend to add or change defendants after discovery, even though the statute of limitations has run, would advance the liberal pleading policy behind the federal rules in general and Rule 15(c) in particular. Second, most courts already focus primarily on notice, rather than mistake, when deciding such cases. ${ }^{25}$ Therefore, so long

more broadly would help to level the playing field in these cases, it would not change any of the substantive rules governing when law enforcement agencies or officers can be liable. Thus, it would help to ensure that meritorious suits are heard, but it would not increase the number of meritorious suits.

22. See Foman v. Davis, 371 U.S. 178, 181 (1962) ("It is too late in the day and entirely contrary to the spirit of the Federal Rules of Civil Procedure for decisions on the merits to be avoided on the basis of such mere technicalities."); Conley v. Gibson, 355 U.S. 41, 48 (1957) ("The Federal Rules reject the approach that pleading is a game of skill $\mathrm{m}$ which one misstep by counsel may be decisive to the outcome and accept the principle that the purpose of pleading is to facilitate a proper decision on the merits.").

23. See Foman, 371 U.S. at 181; Conley, 355 U.S. at 48.

24. See infra Parts I.B.2 and I.B.3.

25. See, e.g., Schiavone v. Fortune, 477 U.S. 21, 31 (1986) ("The linchpin is notice ...."); New York Cent. \& Hudson River R.R. v. Kinney, 260 U.S. 340, 346 (1922) ("[W] hen a defendant has had notice from the begiuning that the plaintiff sets up and is trying to enforce a claim against it because of 
as Rule $15(\mathrm{c})$ 's notice requirements remain intact, broadening the application of relation back is consistent with the philosophy underlying most courts' results, if not their reasoning. Third, denying relation back rewards Doe defendants who obfuscate in order to prevent the plaintiff from ascertaining their identity until the statute of limitations has passed. ${ }^{26}$ Fourth, because a court may deny any motion to amend if it finds that the motion is brought in bad faith or with dilatory motive, ${ }^{27}$ allowing relation back will not encourage plaintiffs to delay needlessly in seeking to determine the identity of the correct defendant.

Finally, Part IV considers how this change can be achieved. This Part argues that the analytical problems presented by Rule 15's mistake clause should be solved, and the reach of relation back should be somewhat extended, through an express amendment to Rule 15(c), rather than broad judicial interpretation or re-interpretation of the Rule's current language. Although some courts ${ }^{28}$ and commentators ${ }^{29}$ suggest that the Rule as written encompasses Doe or similar situations, the majority of circuits to consider this question have held that the Rule does not extend relation back to such circumstances. ${ }^{30}$ Given the actual language used in the current version of the Rule, the majority approach makes sense, because interpreting "mistake" to include a complete lack of knowledge is a strained reading of the text and is unsupported by the Advisory Committee Notes. Consequently, Part IV suggests that the last sentence of Rule 15(c)(3) should be amended to state that relation back is allowed when the other provisions of the Rule are met and the new party "knew or should have known that, but for the movant's lack of knowledge of the proper party, or a mistake con-

specified conduct, the reasons for the statute of limitations do not exist, and we are of the opinion that a liberal nule should be applied."); Heinly v. Queen, 146 F.R.D. 102, 107 (E.D. Pa. 1993) ("The mistake aspect of the Rule is designed to insure that the new defendant knew or should have known within the relevant time period that his joinder was a distinct possibility.").

26. See, e.g., Byrd, 964 F. Supp. at 146 ("To hold that Rule 15(c) does not permit relation back in such circumstances would permit defense counsel to eliminate claims against any John Doe defendant merely by resisting discovery requests until the statute of limitations has ended.").

27. See Foman, 371 U.S. at 182 (holding that a trial court may deny a motion to amend if it finds "undue delay, bad faith, or dilatory motive on the part of the movant").

28. See, e.g., Varlack v. SWC Caribbean, Inc., 550 F.2d 171, 175 (3d Cir. 1977) (holding "mistake" condition satisfied when plaintiff sought to add a defendant originally named as "unknown employee"); Byrd, 964 F. Supp. at 144-46 (holding that plaintiff's inability to discover the true identity constituted a "mistake"); Williams v. Avis Transport of Canada, Ltd., 57 F.R.D. 53, 55 (D. Nev. 1972) (holding that mistake "exists whenever a party who may be liable for the actionable conduct alleged in the Complaint was omitted as a party defendant").

29. See, e.g., Steven S. Sparling, Note, Relation Back of "John Doe" Complaints in Federal Court: What You Don't Know Can Hurt You, 19 CARDozo L. Rev. 1235 (1997) (arguing that Doe substitutions should relate back even under Rule 15 as currently written).

30. See Jacobsen v. Osbome, 133 F.3d 315, 320-21 (5th Cir. 1998); Barrow v. Wethersfield Police Dep't, 66 F.3d 466, 470, amended by 74 F.3d 1366 (2d Cir. 1996); Cox v. Treadway, 75 F.3d 230, 240 (6th Cir. 1996); Wilson v. United States Gov't, 23 F.3d 559, 563 (1st Cir. 1994); Worthington v. Wilson, 8 F.3d 1253, 1256-57 (7th Cir. 1993); Western Contracting Corp. v. Bechtel Corp., 885 F.2d 1196, 1201 (4th Cir. 1989). 
cerning the identity of the proper party, the action would have been brought against the party."31

\section{I}

\section{A Brief History of Relation-Back Doctrine}

The Advisory Committee Note to the original Rule 15(c), adopted in 1937 , states that "[r]elation back' is a well recognized doctrine of recent and now more frequent application." 32 At common law, courts applied a "traditional rule," which limited relation back to amendınents providing more information about an existing claim. Relation back was not allowed for amendinents adding or changing the cause of action ${ }^{33}$ or parties. ${ }^{34} \mathrm{Be}$ ginning around 1900, some federal courts began to take a more liberal approach, but still, in general, application of the doctrine was quite limited. ${ }^{35}$ After the adoption of the federal rules, many courts began to allow amendments adding or changing parties as long as the "new" party was already on notice and before the court. ${ }^{36}$ Rule 15 was revised in 1966 to codify this approach, ${ }^{37}$ and it was at this time that the "but for a mistake" language was introduced. ${ }^{38}$ Although other problems were addressed by the 1991 amendınents to Rule $15,{ }^{39}$ this language has not yet been revisited.

\section{A. Relation Back at Common Law}

During the common law era, courts stated and applied one traditional rule for when an amendment would relate back. Courts continued to give formal allegiance to the traditional rule up until the adoption of the Federal Rules of Civil Procedure im 1937. However, in practice, during the years leading up to the adoption of the federal rules, federal courts began to apply the traditional rule less strictly than had all courts at common law.

At common law, courts allowed amendinents to relate back to the original filing date only in certam limited circumstances ${ }^{40}$ Courts did not allow amendinents that added a new cause of action to relate back. ${ }^{41}$ How-

31. Emphasis indicates suggested new text.

32. FED. R. Crv. P. 15 advisory committee's note to subdivision (c) (1937).

33. See infra notes $40-41$ and accompanying text.

34. See infra notes 54-56 and accompanying text.

35. See infra notes $48-53$ and accompanying text.

36. See infra notes $70-74$ and accompanying text.

37. See infra notes 76-81 and accompanying text.

38. FED. R. Crv. P. 15(c) (1966).

39. See infra notes $92-95$ and accompanying text.

40. See 6 Charles Alan Wright et al., Federal Practice and Procedure $\$ 1471$ (1990) (stating that at common law, amendments that added a new cause of action or changed the cause of action were not allowed); Clif J. Shapiro, Note, Amendments That Add Plaintiffs Under Federal Rule of Civil Procedure 15(c), 50 GEo. WASH. L. REv. 671, 673 (1982) (describing relation-back doctrine at common law).

41. See, e.g., N \& G Taylor Co. v. Anderson, 275 U.S. 431, 438-39 (1928) (affirming denial of lcave to amend a common law contract claim to allege, in additiou, a violation of a state statute after the 
ever, they allowed relation back when the proposed amendments "merely amplifie[d] and g[a]ve[] greater precision to the allegations in support of the cause originally presented, or state[d] new grounds or specifications germane to such charges or allegations." ${ }^{\text {. }} 2$

The theory behind this distinction was that filing a suit and pleading a cause of action interrupted the running of the statute of limitations. ${ }^{43}$ Until the plaintiff pled a cause of action, the statute of limitations applicable to that cause of action ran, regardless of whether the plaintiff pled other claims based on the same occurrence. ${ }^{44}$ The United States Supreme Court explained the rule as follows:

The general rule is, that an amendment relates back to the time of the filing of the original petition, so that the running of the statute of limitations against the amendment is arrested thereby. But this rule, from its very reason, applies only to an amendment which does not create a new cause of action. The principle is, that, as the running of the statute is interrupted, by the suit and summons, so far as the cause of action then propounded is concerned, it interrupts as to all matters subsequently alleged, by way of amendment, which are part thereof. But where the cause of action relied upon, in an amendment, is different from that originally asserted, the reason of the rule ceases to exist, and hence the rule itself no longer applies. ${ }^{45}$

statute of limitations had run); Union Pac. Ry. Co. v. Wyler, 158 U.S. 285, 296-97 (1895) (stating the rule and disallowing relation back for an amendment seeking to change the cause of action from negligence to violation of a state statute); Boston \& M.R.R. v. Hurd, 108 F. 116, 124-25 (1st Cir. 1901) (refusing to grant leave to amend a common law personal injury claim to add a statutory wrongfuldeath claim after the statute of limitations had run); Whalen v. Gordon, 95 F. 305, 311-15 (8th Cir. 1899) (disallowing relation back for an amendment alleging the rescission of a sales contract and seeking the recovery of purchase price paid when the original claim was for damages for an alleged breach of warranty); Shapiro, supra note 40 , at 673 \& n. 14 .

42. Bowles v. Pure Oil Co., 5 F.R.D. 300, 304 (E.D. Pa. 1946) (quoting 34 AM. JuR. $\$ 264$ ); see Shapiro, supra note 40 , at 673 \& nn.14-15. For cases allowing amendments that did not add a new cause of action, see, for example, Atlantic \& Pac. R.R. Co. v. Laird, 164 U.S. 393, 396-403 (1896) (allowing amendment after the statute of limitations had run when the amendment dismissed one of two alleged joint tortfeasors, alleged that the remaining tortfeasor was solely responsible for the alleged injury, stated that the plaintiff traveled on a "ticket" rather than a "first-class ticket," and alleged that the defendant was chartered by an act of Congress instead of the laws of Massachusetts); Mostenbocker v. Shawnee Gas \& Elec. Co., 152 P. 82, 83-86 (Okla. 1915); Love v. Southem Ry. Co., 65 S.W. 475, 475,479 (Tenn. 1901) (allowing relation back for an amendment naming beneficiaries in a wrongful death case when the original complaint had been filed by the administrator only); Missouri Pac. Ry. Co. v. Moffatt, 55 P. 837, 838 (Kan. 1899) (allowing amendment after the statute of limitations had run when the original complaint pled negligence generally and the amended complaint alleged specific ways in which the defendant had been negligent).

43. Union Pac. Ry. Co., 158 U.S. at 296-97.

44. See id.

45. Id.; accord Whalen, $95 \mathrm{~F}$. at 308 (explaining the common law rule). The practice was slightly more fiexible in eourts of equity. See generally WRIGHT ET AL., supra note $40, \S 1471 \& \mathrm{nn} .16-18$. 
Thus, statutes of limitations and the protection they provide for the rights of defendants took precedence over relation back. ${ }^{46}$

Whether an amendment "amplified" the existing claim or instead presented a new and different cause of action was a question that sometimes led to harsh results. On occasion, courts used this test to deny amendments in situations when the amendment would have caused little, if any, surprise or prejudice. ${ }^{47}$ Perhaps because of these cases, federal courts began to take a more liberal approach to relation back even while reciting the traditional rule. ${ }^{48}$ These courts allowed amendments after the statute of limitations had run so long as the amended claims were based solely on facts alleged in the original claim. ${ }^{49}$ For example, in New York Central \& Hudson River Railroad Co. v. Kinney, ${ }^{50}$ the United States Supreme Court upheld a grant of leave to amend to assert a claim under a federal statute instead of under a state statute or the common law. ${ }^{51}$ Balancing the interests served by

46. See Atlantic \& Pac. R.R. Co., 164 U.S. at 401 (explaining that an amendment that did not constitute a new cause of action "could in nowise have injuriously prejudiced" the defendant); Whalen, $95 \mathrm{~F}$. at 308 (stating that relation-back doctrine "is never permitted to deprive the adverse party of any legal defense to the claim presented by the amendment, such as that which arises by virtue of the provisions of the statute of limitations").

47. See, e.g., Lilly v. Charlotte, C. \& A. R. Co., 10 S.E. 932, 932-33 (S.C. 1890). In this case, the widow of a railroad einployee killed on the job brought a wrongful death action under a state statute. The original complaint stated the plaintiff and an unspecified number of "children of tender years were solely dependent for ... support and subsistence upon [the deccased]," and because of his death were "left utterly hopeless and destitute." Id. The complaint did not state explicitly that the plaintiff was the deceased's widow and that the children were the children of the deceased. See id. At trial, the plaintiff's attorney tried to amend to assert the relationship between the plaintiff and the deceased, but the court refused leave to amend on the grounds that the amendment constituted a new cause of action and was barted by the statute of limitations. See id. A familial relationship between the plaintiff and the deceased was required by the state statute under which the action was brought, so the trial court then sustained the defendant railroad company's demurrer. See id. The Supreme Court of South Carolina affirmed, arguing, "True, it is alleged that the plaintiff and children were dependent upon the deceased. But it does not follow that they were dependent because of the fact that they were his wife and children. They might have been dependent, and still not his wife and children. ... the amendment proposed would have entirely changed the nature of the action." Id. See generally WRIGHT ET AL., supra note 40, $\$ 1471$ (describing the common law cause of action test as "wooden").

48. See, e.g., Missouri, Kansas, \& Texas Ry. Co. v. Wulf, 226 U.S. 570, 576 (1913) (stating the traditional rule but allowing an amendment asserting a federal statutory claim instead of a state law claim on the grounds that it was not a new cause of action and was a change "in form rather than in substance"). See generally WRIGHT ET AL., supra note 40 (arguing that the federal courts allowed amendments more liberally because of 28 U.S.C. $\$ 777$, which freed federal courts from following all state procedural rules, and the Supreme Court's more permissive interpretations of the cause of action standard); Shapiro, supra note 40, at 673-74 \& nn.16-17, 21 (arguing that courts "gradually recognized" that allowing relation back when the new claim had the same factual basis as the original claim would be fairer to the plaintiff without "abrogating the policies of statutes of limitations").

49. See, e.g., Viscount de Valle da Costa v. Southern Pac. Co., 176 F. 843, 844-46 (1st Cir. 1910) (reversing a denial of lcave to amend a common law claim to assert a statutory claim after the statute of limitations had run when all of the facts necessary to support the statutory claim had been alleged in the original pleading).

50. 260 U.S. 340 (1922).

51. In this suit for personal injuries resulting from a train collision, the trial court had allowed the plaintiff to amend his complaint to allege that he and the defendant railroad, his employer, were 
statutes of limitations against the value of allowing amendment, the Court emphasized the significance of notice to the defendant. ${ }^{52}$ It stated:

Of course an argument can be made on the other side, but when a defendant has had notice from the beginning that the plaintiff sets up and is trying to enforce a claim against it because of specific conduct, the reasons for the statute of limitations do not exist, and we are of the opinion that a liberal rule should be applied. ${ }^{53}$

Even under this more liberal approach, courts did not allow relation back for amendments that named new or additional parties. ${ }^{54}$ Adding a plaintiff after the statute of limitations had passed would deprive the defendant of the chance to assert the statute of limitations as a defense against the new plaintiff. ${ }^{55}$ Similarly, a defendant added after the statute of limitations had run would be unable to assert the statute of limitations as a defense to the original cause of action. ${ }^{56}$

Thus, during the period directly preceding the adoption of the Federal Rules of Civil Procedure, two somewhat contradictory strains of relationback decisions co-existed. ${ }^{57}$ However, even courts adopting the more liberal approach professed at least formal allegiance to the traditional

engaged in interstate commerce. See id. at 344. This amendment permitted the plaintiff to recover under the federal Employers' Liability Act of April 22, 1908, 45 U.S.C. $\$ 51$ et seq., which required (1) that the plaintiff and defendant be engaged in interstate commerce, and (2) that the plaintiff be the injured employee or a representative of the employee's estate. Courts allowed amendments to satisfy these requirements in many cases involving this statute. See, e.g., Wulf, 226 U.S. at 574-76 (allowing mother of railroad employee killed in train collision to amend her complaint to sue as administratrix rather than in her individual capacity). However, the Supreme Court held that an amendment to assert a claim under this statute based on the employee's death rather than injury was a "new and distinct cause of action" and hence was barred if made after the statute of limitations had passed. Baltimore \& Ohio S.W. R.R. Co. v. Carroll, 280 U.S. 491, 495 (1930) (reversing judgment entered after trial court granted widow of injured railroad employee leave to amend his complaint to assert claim based on his subsequent death).

52. See Kinney, 260 U.S. at 346.

53. Id.

54. See WRIGHT ET AL., supra note $40, \S 1498$ \& nn.1-2 (stating that the "generally accepted rule" prior to 1966 was that plaintiffs and defendants could not be added by amendment after the statute of limitations had run); Shapiro, supra note 40 , at $674 \& \mathrm{nn} .18-20$ (stating that even the courts that allowed amendment more liberally did not extend relation back to amendments adding plaintiffs or defendants). For cases not allowing amendments that added plaintiffs, see, for example, Love $v$. Southern Railway Co., 65 S.W. 475, 476 (Tenn. 1901) (stating that common law rule against amendments asserting new causes of action barred relation back for amendments adding plaintiffs). For cases not allowing amendments that added defendants, see, for example, Davis v. L.L. Cohen \& Co., 268 U.S. 638, 640-41 (1925) (disallowing relation back for an amendment substituting the name of the federal agent designated by statute for the name of the original defendant railroad company).

55. See Shapiro, supra note 40 , at 674 n.20.

56. See id.

57. See supra notes 40-42 (discussing strict application of traditional rule), 48-53 (discussing more liberal application of traditional rule) and accompanying text. 
common law rule, ${ }^{58}$ and no court extended relation back to amendments adding or substituting parties. ${ }^{59}$

\section{B. Relation Back Under the Federal Rules of Civil Procedure}

Rule 15(c) codified the more liberal approach to relation back, thereby extending relation back to more cases than would have been possible under the traditional rule.$^{60}$ However, the original language of the Rule still permitted even those defendants who were on notice of the plaintiff's claim to take advantage of the plaintiff's pleading errors and escape decisions on the merits by asserting the statute of limitations. ${ }^{61}$ The Rule has been amended five times since its promulgation. ${ }^{62}$ Two of these amendments made technical changes only. ${ }^{63}$ Of the three substantive amendments, two narrowed the number of situations in which defendants are able to assert the statute of limitations even though they are on notice of the plaintiff's claim against them. ${ }^{64}$

\section{The Original Rule 15(c)}

The original Rule 15(c) abandoned the common law cause-of-action test for determining when an amendment would relate back. ${ }^{65}$ Instead, the Rule articulated a new standard: Relation back would be allowed for amendments asserting claims or defenses that arose out of the same "conduct, transaction, or occurrence" as the original claim. ${ }^{66}$ Although some courts initially interpreted the new transaction or occurrence test in light of the common law rule, thus barring amendments asserting new causes of

58. See supra note 48 and accompanying text.

59. See supra notes 54-56 and accompanying text.

60. See Bowles v. Pure Oil Co., 5 F.R.D. 300, 303 (E.D. Pa. 1946) (stating that although "[t]he doctrine of relation back of amendments existed long before the adoption of the Rules of Civil Procedure,... Rule 15(c) broadened its application"); WRIGHT ET AL., supra note 40, $\$ 1471$ ("Although virtually all of the component parts of Rule 15 were drawn from existing practice, the overall effect of the rule is an amendment policy that is more liberal than that permitted at common law or under the codes.").

61. See infra note 66 and accompanying text.

62. The Rule was promulgated in 1937. It was amended in 1963, 1966, 1987, 1991, and 1993.

63. The 1987 amendment changed the text of the Rule to gender-neutral language. WRIGHT ET AL., supra note $40, \S 1471$. The 1993 amendment changed the Rule's cross-reference to Rule 4 to conform to changes made to that Rule. FED. R. Crv. P. 15 advisory committee's note (1993).

64. See infra Parts 1.B.2, 1.B.3. These two amendments occurred in 1966 and 1991. The third substantive amendment, which occurred in 1963, clarified when a supplemental pleading is allowed. See FED. R. Crv. P. 15 advisory committee's note (1963).

65. See Shapiro, supra note 40 , at 674 (asserting that Rule 15(c) "abandoned" the common law rule).

66. FED. R. CrV. P. 15(c) (1938). The complete text of the original Rule 15(c) was: "Whenever the claims or defense asserted in the amended pleading arose out of the conduct, transaction, or occurrence set forth or attempted to be set forth in the original plcading, the amendment relates back to the date of the original pleading." Id. 
action, a consensus developed in favor of a more lenient approach. ${ }^{67}$ Thus, Rule 15(c) abandoned the traditional rule, which was used even up to the adoption of the federal rules by state courts and some federal courts, and instead both codified and extended the more liberal approach to relation back taken by some federal courts in the years immediately prior to the adoption of the federal rules. ${ }^{68}$

Although the general rule against adding parties by amendment after the statute of limitations had passed remained, ${ }^{69}$ under Rule 15(c) soine courts began permitting amendments that changed the capacity in which either the plaintiff ${ }^{70}$ or defendant ${ }^{71}$ was made a party to the action. ${ }^{72}$ In addition, some courts allowed amendments to correct "mere misnomers,"73 such as suing the "Pacific Indemnity Company" instead of the "Pacific Indemnity Insurance Company." 74 However, a number of courts did not allow such amendments, on the grounds that a change in capacity or naine was equivalent to a change in parties and constituted a new action, outside

67. For example, in 1939 the Tenth Circuit Court of Appeals disallowed the plaintiff in a wrongful death suit originally brought for the benefit of the surviving spouse from amending his complaint, after the statute of limitations had run, to assert damages on behalf of the deceased's estate. See L.E. Whitham Const. Co. v. Remer, 105 F.2d 371, 375-76 (10th Cir. 1939). The court stated, "We are of the opinion that [Rule 15(c)] is not applicable where the amendment introduces a different and additional claim or cause of action." Id. However, in a similar case some years later, the same court allowed a surviving spouse to amend her complaint to assert damages under a general wrongful death statute instead of under a statute specifically regarding death caused by trains. Denver \& Rio Grande W. R.R. Co. v. Clint, 235 F.2d 445, 446-47 (10th Cir. 1956). The court attempted to distinguish Remer, but its analysis and approach were fundamentally different, and the rationale it used to conclude that this amendment presented a claim arising out of the occurrence as the original complaint could easily have been applied to the amendment at issue in Remer. See id. at 447.

68. See, e.g., Sikes Co. v. Swift \& Co., 10 F.R.D. 68, 68-69, 71 (W.D.N.Y. 1949) (applying Rule 15 (c) and allowing a plaintiff who had originally pled breach of warranty and breach of contract to add an additional claim for breach of warranty based on allegedly reckless and negligent statements made by the defendant to the plaintiff); see also Porter v. Theo J. Ely Mfg. Co., 5 F.R.D. 317, 321 (W.D. Pa. 1946) (describing new standard under Rule 15(c)); sources cited supra note 60 (asserting that Rule 15(c) allowed relation back more broadly than did the common law rule).

69. See supra note 54 .

70. See, e.g., Russell v. New Amsterdam Cas. Co., 303 F.2d 674, 675-76, 680 (8th Cir. 1962) (allowing the plaintiff in wrongful death action to amend her complaint to sue as the personal representative of the deceased's estate rather than in her individual capacity as an heir of the deccased); see also WRIGHT ET AL., supra note 40, 1498 \& n.3 (collecting cases).

71. See, e.g., Porter, 5 F.R.D. at 319-21 (allowing a plaintiff who had originally sued an individual and a corporation to amend the complaint to sue the individual in his capacity as the manager of the corporation); see also WRIGHT ET AL., supra note $40, \S 1498$ \& n.3 (collecting cases).

72. See Shapiro, supra note 40 , at 675 (stating that courts allowed technical amendments changing the capacity in which parties were before the court).

73. Grandey v. Pac. Indem. Co., 217 F.2d 27, 29 (5th Cir. 1954). See generally Shapiro, supra note 40 , at $675 \& \mathrm{n} .32$ (arguing that courts permitted such amendments "because the correct parties were alrcady before the court').

74. See Grandey, 217 F.2d at 27-28 (allowing the plaintiff to amend the complaint to correct the name of the defendant and its state of incorporation). 
the scope of the transaction or occurrence alleged in the original pleading. ${ }^{75}$ The Rule was amended in 1966 to address this inconsistency.

\section{The 1966 Amendments to Rule 15(c)}

In 1966, Rule 15(c) was amended to clarify when amendments "changing" a party would relate back to the time of the original filing. A second sentence was added to the Rule, stating:

An amendment changing the party against whom a clain is asserted relates back if the [same transaction or occurrence test] is satisfied and, within the period provided by law for commencing an action against him, the party to be brought in by amendment (1) has received such notice of the institution of the action that he will not be prejudiced in maintaining his defense on the merits, and (2) knew or should have known that, but for a mistake concerning the identity of the proper party, the action would have been brought against him. ${ }^{76}$

In addition, a sentence was added to clarify that the United States government can be brought into an action by any of several possible approaches, even when a statute requires a certain type of action to be brought against a specific official. ${ }^{77}$

The Advisory Committee Note states that, as revised, the Rule endorsed allowing amendments to change party naines or capacities as long as the "new" defendant was on notice. ${ }^{78}$ In particular, the Note clarifies that the Rule allows amendments that "change" the defendant in suits against the governinent. ${ }^{79}$ The Note explains that relation back should be allowed in such situations because the governinent as a whole, which is effectively

75. See, e.g., Kemer v. Rackmill, 111 F. Supp. 150, 151-52 (M.D. Pa. 1953) (denying leave to amend complaint, which originally named the defendant mdividually and doing business as "Malibou Dude Ranch," to designate the "Malibou Dude Ranch, Inc." as a defendant in addition to the individual, who was the owner and operator of the ranch and was competent to receive service on behalf of the corporation); see also WRIGHT ET Al., supra note $40, \$ 1498$ \& n.2 (describing these results as "harsh" and collecting cases). In 1963, Professor Byse wrote an article criticizing cases in which plaintiffs suing government agencies had had their actions barred because they had not named the correct government entity in time. Clark Byse, Suing the "Wrong" Defendant in Judicial Review of Federal Administrative Action: Proposals for Reform, 77 HaRv. L. REv. 40 (1963). This article influenced the advisory committee as it prepared the 1966 amendments to the Rule. See FED. R. Crv. P. 15 advisory committee's note (1966) (citing Professor Byse's article).

76. FED. R. Crv. P. 15(c) (1966).

77. See id.

78. See FED. R. CIV. P. 15 advisory committee's note (1966); see also WRIGHT ET AL., supra note $40, \$ 1498$ (arguing that the 1966 amendments to Rule $15(\mathrm{c})$ officially sanctioned the more permissive, liberal approach).

79. See FED. R. CIV. P. 15 advisory committee's note (1966); see also Benjamin Kaplan, Continuing Work of the Civil Committee: 1966 Amendments of the Federal Rules of Civil Procedure, 81 HaRv. L. REv. 356, 408-10 (1967). 
the real party in interest, receives notice when the original complaint is filed, notwithstanding formal naming defects. ${ }^{80}$

Although these amendments to the Rule successfully eliminated much of the inconsistency of prior practice, ${ }^{81}$ they added new language that would itself prove problematic. First, the "but for a mistake"82 clause does not address Doe-type situations and has led to harsh and inconsistent results. ${ }^{83}$ Second, the amended Rule left open whether the correct defendant must be on notice before the statute of limitations runs or within the period provided for service, a period which can extend beyond the end of the statute of limitations. ${ }^{84}$ This second problem was addressed by the 1991 amendments to Rule 15(c).

\section{The 1991 Amendments to Rule 15(c)}

In 1991, Rule 15(c) was amended to solve one of the problems that arose after the 1966 amendments. The problem arose as follows. Although the Advisory Committee Note to the 1966 amendments stated that the defendant had to be placed on notice "within the applicable limitations period," notice "within the period provided by law for commencing an action against him." requiring notice before the statute of limitations had run ${ }^{87}$ and some courts accepting notice after the statute of limitations had run but within the applicable period for service. ${ }^{88}$ The United States Supreme Court addressed this issue in a 1986 case, Schiavone v. Fortune. ${ }^{89}$ The Court held that the plain meaning of the language of Rule 15(c) dictated that notice be received within the period provided by the statute of limitations, not the time allowed for service. ${ }^{90}$ Thus, the Supreme Court embraced the results of the first group of courts noted above.

For an example of how this interpretation of the Rule worked, consider a situation in which a plaintiff filed suit against defendants $A$ and $B$ on February 12, 1997, asserting a claim on which the statute of limitations

80. FED. R. Crv. P. 15 advisory committee's note (1966).

81. See supra notes $69-75$ and accompanying text.

82. Fed. R. Crv. P. 15(c) (1966).

83. See infra Part 11.C.

84. See FED. R. CIV. P. 4.

85. FED. R. Crv. P. 15 advisory committee's note (1966).

86. FED. R. CIV. P. 15(c) (1966).

87. See, e.g., Craig v. United States, 413 F.2d 854 (9th Cir. 1969); see also WRIGHT ET AL., supra note $40, \S 1498$ \& n.8 (collecting cases).

88. See, e.g., Kirk v. Cronvich, 629 F.2d 404 (5th Cir. 1980); Ingram v. Kumar, 585 F.2d 566 (2d

Cir. 1978); see also WRIGHT ET AL., supra note 40, § 1498 \& n.10 (collecting cases).

89. 477 U.S. 21 (1986).

90. See id. at 29-31; see also WRIGHT ET AL., supra note 40, § 1498 (discussing Schiavone v. Fortune). 
would run ten days later, on February 22, 1997. The statute of limitations would be met and the plaintiff's suit against $A$ and $B$ could proceed, even though the plaintiff could wait to serve $A$ and $B$ until June 12, 1997, 120 days after filing the suit. If the plaintiff waited until June 12 to serve, $A$ and $B$ would not have received notice of the suit until 110 days after the statute of limitations had run, yet they would be unable to assert the statute as a defense. In contrast, if the plaimtiff tried to amend to add an additional defendant, $C$, on June 12 and served $C$ on the same day, $C$ could successfully assert the statute of limitations as a defense.

Commentators strongly criticized this result, ${ }^{11}$ and in 1991 the Rule was amended for the express purpose of "chang[mg] the result in Schiavone v. Fortune."92 To accomplish this goal, the language "within the applicable limitations period" $"$ was changed to "within the period provided by Rule 4(m) for service of the summons and complaint." ${ }^{.94}$ In addition, a new provision, subsection (c)(1), was added to make clear that a more liberal statute of limitations provision should prevail over the federal rule. ${ }^{95}$ After these changes and the technical 1993 amendment, Rule 15(c) currently provides:

An amendment of a pleading relates back to the date of the original pleading when (1) relation back is permitted by the law that provides the statute of limitations applicable to the action, or (2) the claim or defense asserted in the amended pleading arose out of the conduct, transaction, or occurrence set forth or attempted to be set forth in the original pleading, or (3) the amendinent changes the party or the naming of the party against whom a claim is asserted if the foregoimg provision (2) is satisfied and, within the period provided by Rule 4(m) for service of the summons and complaint, the party to be brought in by amendment (A) has received such notice of the mstitution of the action that the party will not be prejudiced in maintaining a defense on the merits, and (B) knew or should have known that, but for a mistake concerning the identity of the proper party, the action would have been brought against the party. ${ }^{96}$

91. See FED. R. CIV. P. 15 advisory committee's note (1991) (listing law review articles criticizing Schiavone); WrIGHT ET AL., supra note 40, § 1498 \& n.13 (noting that Schiavone was severely criticized and listing articles).

92. FED. R. Crv. P. 15 advisory committee's note (1991).

93. FED. R. CIV. P. 15(c) (1966).

94. FED. R. CIV. P. 15(c) (1991).

95. As amended, Rule 15(c) begins: "An amendment of a pleading relates back to the date of the original pleading when (1) relation back is permitted by the law that provides the statute of limitations applieable to the action ...." Id. See generally FED. R. CIV. P. 15 advisory committee's note (1991) (stating that the purpose of subsection (c)(1) is to make it clear that when the applicable statute of limitations law allows relation back more liberally than does the Rule, the statute of limitations law should prevail).

96. FED. R. CIv. P. 15(c). 
Although the 1991 changes continued the trend, started by the adoption of the Rule itself, toward allowing relation back more broadly and solved the problems caused by the timing language of the 1966 amendments, they did not address the inconsistencies caused by the Rule's "but for a mistake ${ }^{\prime 97}$ language. This problem persists today.

II

Rule 15(c)'s Current “But for a Mistake” Clause

The 1966 and 1991 amendments to Rule 15(c) increased the number of cases in which plaintiffs' attempts to correct errors or name unnamed defendants collide with restrictions on relation back. ${ }^{98}$ These cases can be grouped into three broad categories, explained in detail below. Briefly, the first type of case is the true misnomer, in which amendment is sought to correct a technical, literal error in the naming of a defendant already before the court. The second type of case is mistaken identity, in which amendment is sought to correct errors in naming the legally responsible entity. The third type of case involves the incorporation of new defendants. This type can be broken into two subcategories, semantically different but in substance the same: adding new defendants and substituting named defendants for Does. Courts have used different and sometimes inconsistent reasoning in each of these three situations. Although the results are far from uniform, the majority of courts have held that Rule 15(c) allows relation back only for literal "mistakes" and therefore does not encompass Doe situations or other situations involving originally unnamed defendants.

\section{A. Misnomer}

The first kind of case involves misnomers, or changes to the formal name given a party already before the court. In this situation, the plaintiff initially names $A$ as a defendant, believing $A$ to have characteristics $X, Y$, and $Z$, and then later finds out that $A$ still has those characteristics and is still the correct defendant but is actually named $A^{\prime} . A^{\prime}$ has had notice of the action all along. For example, Sally is injured when the car she is driving is struck by another car. She sues the driver of the other car, naming him in her complaint as "Wayne Johnson." Through discovery Sally learns that the defendant's last name is actually spelled "Johnsen," and she seeks to correct the spelling of his name through an amendment after the statute of limitations has run.

97. Id.

98. See Carol M. Rice, Meet John Doe: It Is Time for Federal Civil Procedure to Recognize John Doe Parties, 57 U. PITT. L. REv. 883, 927-30 \& n.173 (1996) (explaining that the 1966 amendments allowed Doe practice to develop and that, prior to 1991, many such cases were dismissed on grounds of untimely notice). 
Although some courts did not allow relation back for amendments correcting misnomers under the original version of Rule 15(c), ${ }^{99}$ the changes made to the Rule in 1966 clarified that amendments to correct misnomers should relate back as long as the other requirements of the Rule are met. ${ }^{100}$ Since that revision, courts have accepted this portion of the doctrine and have consistently allowed relation back in such cases. ${ }^{101}$ In general, the reasoning used by courts in these cases is that Rule 15(c) plainly contemplates such amendments and that in nearly all, if not all, such situations, the correct defendant is already before the court, is aware that it is being sued, and will suffer no prejudice from the amendment. ${ }^{102}$

\section{B. Mistaken Identity}

The second kind of case is mistaken identity. These cases involve the substitution of a new party for one originally in the suit. Here, the plaintiff initially names $B$ as a defendant, believing it to have characteristics $U, V$, and $W$ that make it the legally liable party according to the substantive law governing the action. The plaintiff later learns that $B$ does not have characteristics $U, V$, and $W$ and hence cannot be liable, but another entity, $C$, has those characteristics and is therefore potentially liable.

Modifying the hypothetical given above, this situation could arise in the following way. Sally is injured when the car she is driving is struck by another car. At the scene, the driver of the other car, Wayne Johnsen, mentions that the car is owned by his friend. Sally brings suit against Wayne and the friend, accomplishing service close to 120 days after the statute of limitations has run. Wayne's friend answers after the period is over, revealing that the car actually belongs to his girlfriend. Sally seeks leave to amend to substitute in the girlfriend. All along Sally has intended to sue the owner of the car (in addition to the driver); she just was mistaken as to the identity of the car's owner. ${ }^{103}$

99. See supra note 75 and accompanying text.

100. See supra Part I.B.2.

101. See, e.g., Pineda v. Almacenes Pitusa, Inc., 982 F. Supp. 88, 90-91, 98 (D.P.R. 1997) (allowing relation back for amendment changing the name of the defendant in an employment discrimination case from "Empresas Koppel d/b/a Almacenes Pitusa" to "Almacenes Pitusa, Inc."); Daniels v. Loizzo, 174 F.R.D. 295, 299-300 (S.D.N.Y. 1997) (granting the plaintiff leave to amend to change a defendant's name from "Fisher" to "Fischer"); Ratcliffe v. Ins. Co. of N. Am., 482 F. Supp. 759, 761-64 (E.D. Pa. 1980) (granting the plaintiff leave to amend the complaint to change the name of the defendant from "Insurance Company of North America Corporation" to "Insurance Company of North America" and "INA Corporation" when the defendants had notice both of the action and the plaintiff's mistake).

102. E.g., Pineda, 982 F. Supp. at 90,98 (noting that the defendant had pointed out the plaintiff's naming error in its first response to the complaint and that it "was not surprised when the amended complaint was filed against it in its proper corporate name").

103. See generally Leonard v. Parry, 219 F.3d 25, 27 (1st Cir. 2000), in which the plaintiff sued Maureen Boulanger, describing her as the driver of the car that hit the plaintiff, and then discovered that actually Kay Parry had been driving the car. 
Most courts allow relation back in such situations. For example, in G.F. Co. v. Pan Ocean Shipping Co. ${ }^{104}$ the plaintiff had ordered goods to be shipped from Taiwan to the United States. ${ }^{105}$ The goods arrived damaged, and the plaintiff brought suit against various parties, including the entity that it thought owned the boat, Panobulk America, Inc. ${ }^{106}$ As it turned out, Panobulk was just the claims agent and another company owned the boat. ${ }^{107}$ The Ninth Circuit upheld the district court's grant of leave for the plaintiff to amend to substitute the shipping company itself as the defendant. ${ }^{108}$ The court held that the plaintiff's "mistake" was in believing that the claims agent, rather than the shipping company, "owned, operated, and controlled" the boat. ${ }^{109}$ Other examples arise in the context of prisoners' civil rights litigation, where plaintiffs, particularly pro se ones, often do not correctly understand at the outset what party can be held liable for the alleged injuries. ${ }^{110}$ In addition to true mistaken identity cases, this category includes cases where the capacity in which a party is sued determines whether or not liability can be imposed. ${ }^{111}$

In a small handful of cases, courts have not allowed relation back for mistaken identities. For example, in Wilson $v$. United States Government, ${ }^{112}$ Wilson was a seaman who alleged that he was injured

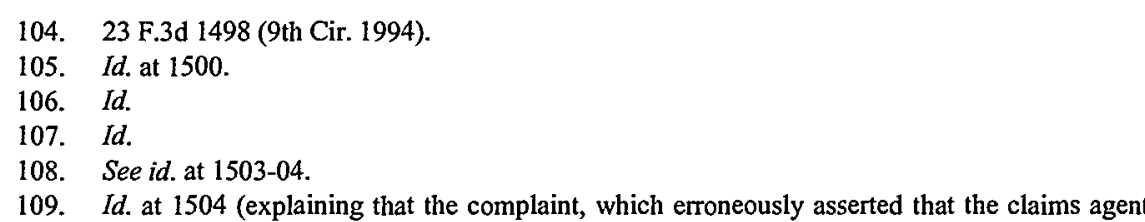
owned the boat, gave the defendants notice that the plaintiff had made a mistake); see also Leonard $\mathrm{v}$. Parry, 219 F.3d 25, 27-29 (1st Cir. 2000) (allowing relation back, in a personal injury suit arising out of a car accident, for an amendment that named the actual driver of the car as a defendant when the complaint incorrectly stated the owner of the car had been driving at the time of the accident).

110. E.g., Soto v. Brooklyn Corr. Facility, 80 F.3d 34, 35-37 (2d Cir. 1996) (holding that a civil rights plaintiff who had named a correctional institution as the defendant, but who had pled facts supporting a claim against the individual officers, should be given leave to amend to name individual officers); Urrutia v. Harrisburg County Police Dep't, 91 F.3d 451, 454, 457-58 (3d Cir. 1996) (remanding in forma pauperis complaint that had been dismissed as legally frivolous to allow the plaintiff to attempt to amend to name individual officers instead of municipal police department); Donald v. Cook County Sheriff's Dep't, 95 F.3d 548, 557 (7th Cir. 1996) ("A legal mistake concerning whether to sue an institutional or individual defendant brings the amendment within the purview of Rule 15(c)(3)(B)."); Mitchell v. Hendricks, 68 F.R.D. 564, 565-66 (E.D. Pa. 1975) (allowing relation back for an amendment changing the name of a defendant described as the superintendent of the institution in which the plaintiff was incarcerated from "James F. Maroney" to "Joseph R. Bricrley").

111. See, e.g., Travelers Ins. Co. v. Hartford Accident \& Indem. Co., 338 F.2d 229, 232-34 (5th Cir. 1964) (upholding denial of defendant's motion to dismiss on statute of limitations grounds when the plaintiff amended the complaint to name Travelers Insurance as "the public liability insurer of Ethyl Corporation, and its executive officers, and directors and stockholders and its other agents, servants and employees" instead of Travelers Insurance as "the public liability insurer of Ethyl Corporation").

112. 23 F.3d 559 (1st Cir. 1994); see also Western Contracting Corp. v. Bechtel Corp., 885 F.2d 1196, 1197-98, 1200-01 (4th Cir. 1989) (denying relation back for a defendant's amendment to assert counterclaims against parties not originally in the action when there was no evidence that the parties had been left out by mistake); Burgin v. La Pointe Mach. Tool Co., 161 F.R.D. 44, $45-47$ (D.S.C. 1995) 
while stranded at sea during a hurricane. ${ }^{113} \mathrm{He}$ originally named his employer, General Electric Government Services, Inc., ${ }^{114}$ as the defendant, apparently thinking that his employer owned the boat. ${ }^{115}$ After the company moved for summary judgment on the grounds that the Navy owned the boat on which Wilson had been stranded, Wilson sought leave to substitute the United States as a defendant. ${ }^{116}$ The First Circuit affirmed the district court's denial of leave to amend. ${ }^{117}$ Although it could have rested its decision on lack of notice to the United States, the court of appeals also analyzed the mistake requirement of Rule 15(c)(3) and concluded that amendments substituting parties fail to meet this test. ${ }^{118}$ The court stated, "Wilson merely lacked knowledge of the proper party.... Wilson fully intended to sue GEGS, he did so, and GEGS turned out to be the wrong party. We have no doubt that Rule 15(c) is not designed to remedy such mistakes." $" 119$

In addition, outside the somewhat specialized context of civil rights actions, ${ }^{120}$ the mistaken identity theory has not been extended to situations in which the plaintiff fails to name a legally responsible entity that could have been named from the outset. For example, im Rendall-Speranza $v$. Nassim, ${ }^{121}$ the court denied relation back for an amendment seeking to name the plaintiff's employer as a defendant in addition to the plaintiff's supervisor, who allegedly had harassed the plaintiff. ${ }^{122}$ The court reasoned that "an error of judgment about whether an employer is liable for the act of its employee is not 'a mistake' within the intendment of Rule 15(c)."'123 The court noted that nothing prevented the plaintiff from suing both her supervisor and her employer on alternative theories of liability from the

(holding that an amendment to add an additional manufacturer in a product liability action did not relate back because the plaintiff had not made a mistake but just did not know about the additional manufacturer); Helmac Prods. Corp. v. Roth (Plastics) Corp., 814 F. Supp. 560, 562-63 (E.D. Mich. 1992) (denying relation back for amendment adding individual as defendant in action originally filed against corporation and asserting that "Rule $15(\mathrm{c})$ permits the naming of new parties only in cases of misnoiner").

113. See Wilson, 23 F.3d at 560 .

114. This entity was a private corporation, not an agency of the government. See id. (describing this defendant as a "private party").

115. See id.

116. See id.

117. See id. at 562-63.

118. See id.

119. Id. at 563 .

120. See supra note 110. Because of the significant body of law about the capacity in which a defendant must be sued and which defendant is the proper defendant for a civil rights action, and perhaps also because of the fact that many civil rights plaintiffs are pro se, courts seem to allow more latitude im such cases than in similar situations arising im other areas of law.

121. 107 F.3d 913 (D.C. Cir. 1997).

122. Id. at 915,919 .

123. Id. at 918 . 
beginning of the case. ${ }^{124}$ Thus, the mistaken identity situation arises when the plaintiff knows from the beginning the substantive characteristics of the proper defendant but misidentifies which entity has those characteristics, not when the plaintiff just fails at the outset to name an additional entity that could be liable.

\section{Additional Defendants and Doe Substitutions}

The third kind of case consists of situations where the plaintiff lacks knowledge of a correct defendant's identity at the outset of the litigation. Such situations can arise in two similar yet slightly different ways: either when the plaintiff had no idea this new defendant existed at the outset of the litigation, or when the plaintiff knew such an entity existed but did not know its name and therefore sued a "John Doe." In general, the majority of courts do not allow relation back in such situations, holding that in either case the plaintiff has not made a "mistake" as required by the Rule.

\section{Additional Defendants}

The non-Doe version of this situation arises in the following way. The plaintiff originally brings suit against $D$. After discovery, the plaintiff learns that an entirely different party with different characteristics, $E$, may also be liable. The existence of $E$ does not negate the possibility that the original defendant $D$ may be liable and $E$ does not replace $D$. Instead, the plaintiff seeks to add $E$ as an additional defendant.

Returning to Sally and her car accident, this type of case would occur if during discovery Sally learned that driver Wayne had been drinking heavily at a local bar before the accident. Sally seeks to amend after the statute of limitations has run to name the owner of the bar as an additional defendant. Sally alleges that the owner was negligent in serving Wayne so much alcohol and allowing him to drive away.

Several Third Circuit district court decisions have allowed relation back in this kind of case. ${ }^{125}$ Citing one of these Third Circuit district court decisions, the Eleventh Circuit has also allowed relation back in one such case. $^{126}$ One Ninth Circuit district court decision also took this

124. Id. at 919.

125. See, e.g., Advanced Power Sys., Inc. v. Hi-Tech Sys., Inc., 801 F. Supp. 1450, 1453, 1455 , 1457 (E.D. Pa. 1992) (allowing relation back when defendants originally named the plaintiffs' company as a counterclaim defendant and later sought to amend to name the plaintiffs as individual counterclaim defendants as well); Gabriel v. Kent Gen. Hosp. Inc., 95 F.R.D. 391, 392-95 (D. Del. 1982) (allowing the plaintiff in an action arising out of a car accident to amend complaint originally filed against the company that brokered the driver to add the company that supplied the truck); Taliferro v. Costello, 467 F. Supp. 33, 34-36 (E.D. Pa. 1979) (allowing the plaintiffs in a $\$ 1983$ action originally brought against the city's deputy sheriff to add the city as an additional defendant).

126. Itel Capital Corp. v. Cups Coal Co., Inc., 707 F.2d 1253, 1258 \& n.9 (11th Cir. 1983) (allowing relation back for an amendment adding the president of the company that was the original defendant as an additional defendant; citing Taliferro, 467 F. Supp. at 34-36). In a later case, however, 
approach. ${ }^{127}$ These courts view a plaintiff who originally believed $D$ to be the proper defendant, but then learns that $E$ may be, as having made a "mistake concerning the identity of the proper party," Rule. ${ }^{129}$ One court stated that when a plaintiff seeks to add a defendant and the other requirements of Rule 15(c) are satisfied, "a possibility that the plaintiff may have made a mistake in selecting the original defendants is sufficient to mvoke the Rule."130 Practice within the Eighth Circuit is split or uncertain. ${ }^{131}$

However, most courts do not allow relation back in this kind of situation. The Fourth, ${ }^{132}$ Sixth, ${ }^{133}$ and Seventh ${ }^{134}$ Circuits have considered the issue and denied relation back. While not setting forth as firm a rule as that of the Fourth and Seventh Circuits, the Second Circuit has also denied re-

a district court within the Eleventh Circuit denied relation back in similar circumstances. See Wells v. HBO \& Co., 813 F. Supp. 1561, 1566-67 (N.D. Ga. 1992) (denying relation back for an amendment seeking to name four company officers as individual defendants in a securities class action originally brought against the company). The court distinguished Itel on the grounds that "even the most liberal interpretation of 'mistake' cannot include a deliberate decision not to sue a party whose identity plaintiff knew from the outset." Id. at 1567. A more recent Eleventh Circuit case, while distinguishable from Itel, similarly casts doubt on it. See Powers v. Graff, 148 F.3d 1223, 1226-27 (11th Cir. 1998) (holding that a securities action's plaintiffs did not make a "inistake" when they simply failed to name potential individual defendants at the onset of the suit). But see Bowden v. Wal-Mart Stores, Inc., 124 F. Supp. 2d 1228, 1242 (M.D. Ala. 2000) (adopting a very broad view of what constitutes a "mistake").

127. Meredith v. United Air Lines, 41 F.R.D. 34, 36-37, 39 (S.D. Cal. 1966) (allowing relation back for an amendment adding Lockheed as a defendant in addition to the original defendant, the United States, in a tort action arising out of a near crash between a commercial airplane and a militarytype plane labeled with United States insiguia).

128. FED. R. CIV. P. 15(c)(3).

129. See supra notes $125-127$.

130. Gabriel, 95 F.R.D. at 395.

131. Compare McCurry v. Allen, 688 F.2d 581, 584-85 (8th Cir. 1982) (remanding civil rights suit in which the plaintiff sought leave to amend to add additional individual officers as defendants for a determination of whether the 15(c) factors had been met), with Russ v. Ratliff, 578 F.2d 221, 224 (8th Cir. 1978) (holding that a civil rights plaintiff's failure to name the city as a defendant originally was not a mistake). District courts within the Eighth Circuit have denied relation back. See Antinore v. Alexander \& Alexander Servs., Inc., 597 F. Supp. 1353, 1356-57 (D. Minn. 1984) (denying relation back for an amendment adding an insurance brokerage company as a defendant in a securities class action); Upshaw v. Equitable Life Assurance Soc'y, 85 F.R.D. 674, 677-78 (E.D. Ark. 1980) (denying relation back for an amendment adding Retirement Board as a defendant in addition to the employer and the insurer in case arising out of a denial of retirement-related medical treatment benefits).

132. Western Contracting Corp. v. Bechtel Corp., 885 F.2d 1196, 1200-01 (4th Cir. 1989) (denying relation back for an amendment joining three of the plaintiff company's employees as thirdparty defendants after the statute of limitations had run).

133. In re Kent Holland Die Casting \& Plating Inc., 928 F.2d 1448, 1449-50 (6th Cir. 1991) (denying relation back for an amendment adding a new defendant on the theory that Rule 15 reaches only party substitutions, not additions of parties); see also Helmac Prod. Corp. v. Roth (Plastics) Corp., 814 F. Supp. 560, 563 (E.D. Mich. 1992) (denying relation back for an amendment naming the original corporate defendant's principal as an additional, individual defendant).

134. Rylewicz v. Beaton Servs., Ltd., 888 F.2d 1175, 1177-78, 1181 (7th Cir. 1985) (denying relation back for an amendment adding defendants who were unrelated to the original defendants and had not concealed their identities). 
lation back in this type of situation. ${ }^{135}$ District courts within the First, ${ }^{136}$ Tenth, ${ }^{137}$ and District of Columbia ${ }^{138}$ Circuits also have denied relation back. These courts usually reason that the plaintiff in such a situation is not mistaken as required by the Rule. ${ }^{139}$ They hold that being unaware, for whatever reason, that another potential defendant exists is not a mistake, but is instead just a lack of knowledge, one that could perhaps be perceived as a tactical choice, and that the Rule does not reach such situations. ${ }^{140}$

\section{Doe Substitutions}

In true Doe situations, the plaintiff knows at the outset that she is unable to name a potentially liable entity. She attempts to preserve her ability to bring in this defendant later, after she has learned its identity through discovery, by pleading a Doe. For example, if Sally knows that the driver of the car was Wayne Johnsen and she knows that he had been drinking, but prior to discovery she does not know the location of the bar or the name of its owner, she might sue both Wayne and a John Doe.

The circuits are split on whether to allow relation back for Doe substitutions. Four circuits appear to be solidly against allowing relation back. The Fifth, ${ }^{141}$ Seventh, ${ }^{142}$ and Eleventh ${ }^{143}$ Circuits do not allow relation back. Although several district courts within the Sixth Circuit allowed

135. Cornwell v. Robinson, 23 F.3d 694, $704-05$ (2d Cir. 1994) (denying relation back for an amendment naming new defendants whose identities were known to the plaintiff at the time she filed suit and who were described in the body of the original complaint); see also Messina v. Mazzeo, $854 \mathrm{~F}$. Supp. 116, 146-47 (E.D.N.Y. 1994) (denying relation back for an amendment adding the City of New York as a defendant in a $\$ 1983$ action originally brought against police and correctional officers). Second Circuit district courts have also denied relation back for amendments seeking to add new unnamed Doe defendants, not seeking to substitute a named defendant for a previous Doe, after the statute of limitations has run. See, e.g., Daniels v. Loizzo, 174 F.R.D. 295, 300-01 (S.D.N.Y. 1997); Watkins v. Kane, 91 F.R.D. 492, 493 (S.D.N.Y. 1981).

136. Rogatz v. Hosp. Gen. San Carlos, Inc., 89 F.R.D. 298, 301 (D.P.R. 1980) (denying relation back for an amendment adding the insurer of the original defendant, a hospital, as an additional defendant).

137. Manildra Milling Corp. v. Ogilvie Mills, Inc., 746 F. Supp. 40, $41-43$ (D. Kan. 1980) (denying relation back for an amendment seeking to add the subsidiary company of original defendant).

138. King v. Udall, 266 F. Supp. 747,749 (D.D.C. 1967) (denying relation back for an amendment adding private oil companies as defendants in a suit brought against the Secretary of the Interior by an unsuccessful applicant for a public lands lease).

139. See supra notes 132-138.

140. For example, in Rogatz the court states: "This is not a case involving a misnomer of defendant which Rule 15(c) was envisioned to correct. Rule 15(c)(2) permits an amendment to relate back where there has been an error made concerning the identity of the proper party and where that party is chargeable with knowledge of the mistake, but it does not permit relation back where as here, there is lack of knowledge of the proper party." Rogatz, 89 F.R.D. at 300-01.

141. Jacobsen v. Osborne, 133 F.3d 315, 317, 320-22 (5th Cir. 1998).

142. Worthington v. Wilson, 8 F.3d 1253, 1257 (7th Cir. 1993); Wood v. Worachek, 618 F.2d 1225, 1230 (7th Cir. 1980).

143. Wayne v. Jarvis, 197 F.3d 1098, 1103 (11th Cir. 1999). 
relation back for Doe substitutions in the past, ${ }^{144}$ a 1996 Sixth Circuit case denied relation back and seems to foreclose relation back in the future. ${ }^{145}$ One circuit, the Third, allows relation back. ${ }^{146}$ In three circuits, practice is split: Although the Second Circuit has denied relation back for a Doe substitution, ${ }^{147}$ district courts within the second circuit have allowed relation back for Doe substitutions by distinguishing the relevant Second Circuit precedent. ${ }^{148}$ Although no Ninth Circuit case definitively sets out what approach lower courts should take, ${ }^{149}$ district courts within the Ninth Circuit seein to be split. ${ }^{150}$ The same is true for the First ${ }^{151}$ and Tenth Circuits. ${ }^{152}$

144. O'Brien v. City of Grand Rapids, 783 F. Supp. 1034, 1039-40 (W.D. Mich. 1992); Richmond v. McElyea, 130 F.R.D. 377, 382 (E.D. Tenn. 1990); Simpson v. City of Maple Heights, 720 F. Supp. 1303,1306 (N.D. Ohio 1988).

145. See Cox v. Treadway, 75 F.3d 230, 239-41 (6th Cir. 1996). The court in Cox denied relation back for an amendment substituting named defendants for "unknown police officers" in an arrestee's police brutality civil rights suit; the court stated that amendments to add "new parties ... do not satisfy the 'mistaken identity' requirement of Rule 15(c)(3)(B)." Id. at 240. The court also stated that on the facts of the case, knowledge of the suit could not be imputed to the new defendants, thereby distinguishing a prior Sixth Circuit case, Berndt $v$. Tennessee, 796 F.2d 879 (6th Cir. 1989). Id. These positions are somewhat contradictory. If a Doe substitution can never be a mistake, then the mistake requirement of Rule 15(c) will never be met and relation back should never be allowed, regardless of whether the new defendants have notice of the suit.

At least some district courts within the Sixth Circuit have not followed Cox's suggestion that no Doe substitution will ever constitute a mistake. In Henderson v. Hackel, 170 F.R.D. 430, $432-34$ (E.D. Mich. 1997), the district court distinguished Cox and allowed relation back for a Doe substitution, but without analyzing Cox. Another district court analyzed $C o x$ in the context of prior Sixth Circuit precedent and concluded that to the extent $C o x$ intimated that Doe substitutions could never satisfy the mistake requirement, it was inconsistent with Berndt and thus did not accurately state Sixth Circuit law. Daily v. Monte, 26 F. Supp. 2d 984, 985-87 (E.D. Mich. 1998).

146. Varlack v. SWC Caribbean, Inc., 550 F.2d 171, 175 (3d Cir. 1977); Heinly v. Queen, 146 F.R.D. 102, 107 (E.D. Pa. 1993).

147. See Barrow v. Wethersfield Police Dep't, 66 F.3d 466, 469-70 (2d Cir. 1995), as modified by 74 F.3d 1366 (2d Cir. 1996).

148. See Byrd v. Abate, 964 F. Supp. 140, 145, 147 (S.D.N.Y. 1997) (allowing relation back and distinguishing contrary Second Circuit precedent on the grounds that the new defendants had notice); Felix v. New York City Police Dep't, 811 F. Supp. 124, 128 (S.D.N.Y. 1992) (allowing relation back and distinguishing contrary Second Circuit precedent on the grounds that the allegations in Felix's complaint, which included physical descriptions of the Does, were specific enough to put them on notice); Hodge v. Ruperto, 739 F. Supp. 873, 881 (S.D.N.Y. 1990) (allowing relation back and distinguishing contrary Second Circuit precedent on the grounds that Hodge's complaint was specific enough to give the new defendants notice).

149. The Ninth Circuit addressed a Doe substitution in Craig v. United States, 413 F.2d 854 (9th Cir. 1969). However, it denied relation back in that case on the grounds that there was no notice, leaving open whether such an amendment would also fail under the mistake clause. Id. at 857 .

150. Compare Swartz v. Gold Dust Casino, Inc., 91 F.R.D. 543, 547 (D. Nev. 1981) (allowing relation back), and Williams v. Avis Transport, 57 F.R.D. 53, 55 (D. Nev. 1972) (same), with Keller v. United States, 667 F. Supp. 1351, 1357-58 (S.D. Cal. 1987) (denying relation back on the grounds that the plaintiff delayed so long in seeking to amend that the new defendant would have been justified in thinking it was not going to be named).

151. Compare Ortiz v. Betancourt Lebron, 146 F.R.D. $34,41-42$ (D.P.R. 1992) (allowing relation back), with Stewart v. Robinson, 115 F. Supp. 2d 188, 196-97 (D.N.H. 2000) (denying relation back).

152. Compare Sitarz v. Buchner, 652 F. Supp. 95, 100-01 (D.N.M. 1986) (denying relation back on notice grounds, thereby suggesting that a Doe substitution could satisfy the mistake requirement), 
Although the Eighth Circuit has not yet addressed the issue, district courts within it have allowed relation back for Doe substitutions. ${ }^{153}$

Courts that deny relation back for Doe substitutions provide different rationales. ${ }^{154}$ Some courts hold that because a Doe is pled when the plaintiff lacks knowledge of the defendant's identity and name, it is not a "mistake" and therefore is not included under Rule 15(c). ${ }^{155}$ The reasoning given by the Seventh Circuit in Wood v. Worachek ${ }^{156}$ is typical of these cases:

Rule 15(c)(2) permits an amendment to relate back only where there has been an error made concerning the identity of the proper party and where that party is chargeable with knowledge of the mistake, but it does not permit relation back where, as here, there is a lack of knowledge of the proper party. ${ }^{157}$

Other courts gloss over the question of whether or not the plaintiff made a "mistake" and focus on the notice requirements, holding that pleading a Doe does not give the actual party sufficient notice, either of the action or of the plaintiff's mistake. ${ }^{158}$ This line of reasoning leaves open the possibility of relation back for a Doe substitution, if, under the circumstances, the correct defendant had notice.

The decisions that allow relation back for Doe substitutions generally reason that whenever a plaintiff does not know a defendant's identity, the plaintiff has made a "mistake concerning the identity of the proper party,"159 as required by Rule 15(c). For example, in Williams v. Avis Transport of Canada, Ltd. ${ }^{160}$ the district court stated that a mistake "exists

with Henry v. FDIC, 168 F.R.D. 55, 59-60 (D. Kan. 1996) (denying relation back on the grounds that a Doe substitution can never be a mistake).

153. See Ames v. Vavreck, 356 F. Supp. 931, $941-42$ (D. Minn. 1973) (allowing relation back for an amendment substituting named police officers for Does on the grounds that conversations between the plaintiff's attorney and the defendants' attorney gave notice that the individual officers would be substituted in).

154. See generally Rice, supra note 98, at 930-39 (discussing the reasoning used by courts that do not allow relation back for Doe substitutions).

155. See, e.g., Jacobsen v. Osborne, 133 F.3d 315, 317, 320-22 (5th Cir. I998) (denying relation back in a police brutality case for an amendment substituting named police officers for Doe defendants); Barrow v. Wethersfield Police Dep't, 66 F.3d 466, 469-70 (2d Cir. 1995), modified, 74 F.3d 1366 (2d Cir. 1996) (denying relation back in factual situation similar to that of Jacobsen); Cox v. Treadway, 75 F.3d 230, 240 (6th Cir. 1996) (denying relation back where original complaint was filed against "unknown police officers"); Wood v. Worachek, 6I8 F.2d 1225, I230 (7th Cir. 1980) (same).

156. 618 F.2d 1225 (7th Cir. 1980).

157. Id. at 1230 (citation omitted). For similar reasoning, see, for exampIe, Barrow, 66 F.3d at 470 ("[T]he failure to identify individual defendants ... cannot be characterized as a mistake."); Worthington v. Wilson, 8 F.3d 1253, I257 (7th Cir. 1993) ("[F]ailure to name Wilson and WaIl [as defendants] was due to a lack of knowledge as to their identity, and not a mistake in their names.").

158. See, e.g., Perri v. Daggy, 776 F. Supp. I345, 1349-50 (N.D. Ind. 1991) (denying relation back for amendment substituting a named defendant for a Doe defendant in a police brutality case and focusing on lack of notice).

159. FED. R. Clv. P. 15(c)(3).

160. 57 F.R.D. 53 (D. Nev. 1972). 
whenever a party who may be liable for the actionable conduct alleged in the Complaint was omitted as a party defendant." this extremely broad language in a later case in which it allowed an amendment substituting a named defendant for a Doe. ${ }^{162}$ Other courts have used similar but slightly different reasoning, holding that the mistake requirement is met when the new defendant knows that the plaintiff intends to sue the new defendant. ${ }^{163}$

\section{III \\ Why Relation Back Should Be Allowed for Amendments Naming Previously UnNamed Defendants Who ARe on Notice}

When an amendment to name a defendant relates back, the defendant loses the protection provided by the statute of limitations. The primary purpose of statutes of limitations is to ensure that defendants have notice of an action agamst them before evidence has been lost or becoines unavailable and with enough time to prepare an adequate defense. ${ }^{164}$ Relation back is only proper when these policy goals have been met. When the intended defendant is on notice of the action and that it is the intended defendant, it will be able to prepare a defense before the evidence spoils and before it is time for trial. Thus as long as there is notice, the policies behind the statute of limitations are met in the three situations discussed above. Therefore, relation back should be allowed.

This Part considers more fully several reasons why relation back should be allowed in all three amendment situations discussed above. Allowing relation back in these situations would advance the purpose of the federal rules in general and Rule 15(c) in particular, which is to create consistent and fair results while, as much as possible, allowing decisions to be made on the merits rather than on technicalities. In addition, the approach currently taken by the majority of courts rewards defendants who purposefully seek to hide their identities. Finally, allowing relation back in these situations would not decrease the diligence required of plaintiffs, because courts could still deny leave to amend when the amendment would prejudice the defendant or when the plaintiff delayed unduly or acted im bad faith.

161. Id. at 55 .

162. Swartz v. Gold Dust Casino, Inc., 91 F.R.D. 543, 547 (D. Nev. 1981) (allowing the plaintiff in a personal injury case against a casino to anend her complaint to name the owner of the casino in place of a Doe).

163. E.g., Varlack v. SWC Caribbean, Inc., 500 F.2d 171, 175 (3d Cir. 1977); Heinly v. Queen. 146 F.R.D. 102, 107 (E.D. Pa. 1993) ("The mistake aspect of the Rule is designed to insure that the new defendant knew or should have known within the relevant time period that his joinder was a distinct possibility."); Ames v. Vavreck, 356 F. Supp. 931, 942 (D. Minn. 1973) ("Under th[e] circumstances it is inconceivable that the additional defendants ... had no reason to believe that suit might be brought against them.").

164. See Shapiro, supra note 40 , at $672 \&$ nn.6-9. 


\section{A. Expanding Relation Back Would Advance the Purposes of the Federal Rules and Rule 15(c) in Particular}

As long as Rule 15(c)'s notice requirements are met, allowing amendments adding defendants or substituting named defendants for Does ${ }^{165}$ to relate back would advance the general policy behind the federal rules as well as the specific policy underlying Rule 15(c)'s relation-back provision.

Extending relation back would serve to advance the purpose of the federal rules. As both courts ${ }^{166}$ and commentators have noted on numerous occasions, the purpose of the federal rules is to facilitate decisions on the merits rather than on technicalities. ${ }^{167}$ Although in general the statute of limitations and the repose it provides for potential defendants ${ }^{168}$ is more than a "mere technicalit[y],"169 courts applying the majority approach have denied relation back in cases where the intended defendants were fully aware that the plaintiff was trying to sue them, but the plaintiff had not yet formally named the intended defendants. ${ }^{170}$ In such a situation, the plaintiff's failure to formally name the intended defendants is nothing more than a procedural technicality. In such cases, the majority approach contravenes the purpose of the federal rules.

Extending relation back would also advance the policy underlying Rule 15(c). Rule 15(c) was drafted with the conscious intent of endorsing and adopting the more liberal relation-back practice that had begun to develop in the federal courts. ${ }^{171}$ The intent of the 1966 amendment was to clarify that amendments changing a party or the name of a party should relate back as long as doing so does not "offend[]" the policies encapsulated by the statute of limitations. ${ }^{172}$ After discussing several cases

165. See supra Part 11.C.

166. See, e.g., Foman v. Davis, 371 U.S. 178, 181 (1962) ("It is too late in the day and entirely contrary to the spirit of the Federal Rules of Civil Procedure for decisions on the merits to be avoided on the basis of such mere technicalities."); Conley v. Gibson, 355 U.S. 4I, 48 (1957) ("The Federal Rules reject the approach that pleading is a game of skill in which one misstep by counsel may be decisive to the outcome and accept the principle that the purpose of pleading is to facilitate a proper decision on the merits.").

167. See FED. R. CIV. P. 1 (stating that the rules should be construed "to secure the just, speedy, and inexpensive determination of every action"). While deciding cases on technicalities may sometimes be speedy and inexpensive, it usually is not just.

I68. See Shapiro, supra note 40, at 672 \& nn.6-9 (describing the purpose of statutes of limitations as protecting defendants from the prejudice that could result when "surprise[d with] a stale claim").

I69. Foman, 37I U.S. at 181 (describing decisions based on "mere technicalities" as contrary to the spirit of the rules).

I70. E.g., Ford v. Hill, 874 F. Supp. 149, 153-54 (E.D. Ky. 1995).

I71. See supra Parts I.A and I.B.1.

172. FED. R. Crv. P. 15 advisory committee's note (1966); see also Schiavone v. Fortune, 477 U.S. 21, 38 (1986) (Stevens, J., dissenting) ("The principaI purpose of rule 15(c) is to enable a plaintiff to correct a pleading error after the statute of limitations has nu if the correction will not prejudice his adversary in any way."); Rendall-Speranza v. Nassim, 107 F.3d 913, 918 (D.C. Cir. 1997) ("[T]he 
in which plaintiffs suing the government had their actions barred because they did not discover that they needed to name a different branch of the government as the defendant until after the statute of limitations had run, the Advisory Committee Note to the 1966 amendment discusses the "intimate[]" connection between relation back and "the policy of the statute of limitations." "173 The Note states that allowing relation back in these cases would not undermine the goals served by the statute of limitations because the correct defendant was already on notice. ${ }^{174}$

Denying relation back for amendments adding new defendants or making Doe substitutions contravenes this policy. The strictest approach to this situation, exemplified by the Seventh Circuit's Wood v. Worachek ${ }^{175}$ decision, which held that Doe substitutions can never satisfy Rule 15(c)'s mistake requirement, would deny relation back even when the intended defendant has had actual notice of the instigation of the action and that it a potential defendant $\mathrm{m}$ that action. ${ }^{176}$ This approach grants defendants more protection than is necessary according to the philosophy expressed in the Advisory Committee Note. ${ }^{177}$

For example, in Daily v. Monte ${ }^{178}$ the district court allowed relation back for Doe substitutions im a prisoner's civil rights suit against various correctional officers who had allegedly failed to protect the plaintiff froin assaults by fellow prisoners. ${ }^{179}$ The court held that the new defendants had notice of the suit because they were represented by the same attorney as the

evident purpose of the rule... is to avoid the harsh consequences of a mistake that is neither prejudicial nor a surprise to the misnamed party.").

173. FED. R. CIV. P. 15 advisory committee's note (1966).

174. Id.

175. 618 F.2d 1225 (7th Cir. 1980).

176. See id. at 1230 .

177. See FED. R. Civ. P. 15 advisory committee's note (1966); see also Sparling, supra note 29, at 1238-39 (arguing that allowing relation back for amendments substituting named defendants for Does advances the purpose of Rule 15(c)). Further, an approach so strict that any amendment bringing in a new defendant would be barred conflicts with the explicit language of Rule 15(c), which states that it applies to amendments "chang[ing] the party... against whom a claim is asserted" in addition to amendments changing the naming of the party. FED. R. Crv. P. 15(c); see also Donald v. Cook County Sheriff's Dep't, 95 F.3d 548, 561 (7th Cir. 1996) ("The district court ... [stated] that an amended complaint joining new parties does not relate back under [Rule] 15(c). This proposition is, of course, not true as a general matter since one of the major purposes of Rule 15(c) is to determine when an amended complaint joining new parties will relate back.") (internal quotation marks omitted); Woods v. Indiana Univ.-Purdue Univ. at Indianapolis, 996 F.2d 880, 888 (7th Cir. 1993) ("[T] he Rule's language also expressly contemplates the prospect of the retrospective application of an amended coinplaint to a defendant who was not named originally but who was added only later.").

178. 26 F. Supp. 2d 984 (E.D. Mich. 1998).

179. Id. at 984-85. The court allowed relation back notwithstanding the Sixth Circuit's Cox v. Treadway decision a couple of years earlier, which had stated that Doe substitutions are not mistakes. Cox v. Treadway, 75 F.3d 230, 240 (6th Cir. 1996) ("[N]ew parties may not be added after the statute of limitations has run, and ... such amendments do not satisfy the 'mistaken identity' requirement of Rule 15(c)(3)(B)."). The Daily court discussed Cox, concluding that to the extent it suggested that Doe substitutions could never satisfy Rule 15 (c)'s mistake requirement, it did not correctly reflect prior Sixth Circuit precedent. Daily, 26 F. Supp. 2d at 985-87. 
original defendants and had been named in incident reports and interrogatory responses provided by the original defendants during initial discovery, which indicated to the court that the original defendants had talked to the new defendants about the suit soon after it was filed. ${ }^{180}$ Further, the court held that the new defendants had notice that they were intended defendants because the seriousness of the plaintiff's allegations suggested that a thorough investigation must have occurred and because the plaintiff's complaint included enough details about the assault that the new defendants would have known that they were the individuals referred to in the complaint as Does. ${ }^{181}$ The court explained that because the new defendants had timely notice, both of the suit and of the fact that they were the intended defendants, the policies behind the statute of limitations and the relationback provision of Rule 15(c) were met:

[M]y conclusions with respect to the Defendants' awareness of the suit and their potential liability are consistent with the policy objectives of [Rule] 15(c). As several courts have noted, because the Rule creates an exception to the statute of limitations, the issue of whether the requirements of the Rule have been met "must be evaluated in light of the policy objectives of the statute of limitations, i.e., to avoid undue surprise, to permit investigation and collection of evidence while it is fresh and other similar concerns." In the instant case, none of the newly named Defendants will suffer undue surprise, nor will they suffer as a result of stale evidence. Indeed the facts before me suggest that these Defendants were aware of the suit and their potential liability. Moreover, the attorney representing them had begun investigation and collecting evidence regarding the claims against them before they were formally named. ${ }^{182}$

Further, that most courts allow relation back for mistaken-identity amendments ${ }^{183}$ suggests that the policies of the statutes of limitations are met even for amendments bringing in "new" defendants. Relation back is usually not allowed in Doe-type situations, but it is allowed in mistakenidentity cases. These results are unsatisfactory for two reasons. First, both scenarios produce the same result in fact: the addition of a new party. Although amendments in mistaken-identity cases more clearly mvolve "mistakes" than do amendments adding additional defendants or substituting named defendants for Doe defendants, the effect in both is to bring in a new party who was not a party to the case originally. Second, plaintiffs

180. Daily, 26 F. Supp. 2d at 987 ('Such investigation is the only way that Defendants' counsel could have prepared the responses to Plaintiff's interrogatories and requests to admit in early February.").

181. Id.

182. Id. at 988 (citations omitted). For an example of similar reasoning, see Henderson v. Hackel, 170 F.R.D. 430,434 (E.D. Mich. 1997).

183. See supra Part 11.B. 
who are aware of their lack of knowledge should not fare worse than ignorant plaintiffs. The only difference between mistaken-identity cases and additional defendant or Doe substitution cases is that in the former, plaintiffs do not know that they, in fact, are not aware of the correct defendant's identity whereas in the latter, plaintiffs are aware that they lack this knowledge and proceed accordingly. Plaintiffs who know that they do not know the naine of the correct defendant should not be in a worse position than plaintiffs who incorrectly name the wrong defendant, as in both situations the effect of an amendinent is to bring in a new party. Although amendments in mistaken-identity cases more clearly involve "mistakes" than do amendinents adding additional defendants or substituting named defendants for Doe defendants, the effect in both is to bring in a new party who was not a party to the case originally. Second, plaintiffs who are aware of their lack of knowledge should not fare worse than ignorant plaintiffs. The only difference between mistaken-identity cases and additional defendant or Doe substitution cases is that in the former, plaintiffs do not know that they, in fact, are not aware of the correct defendant's identity whereas in the latter, plaintiffs are aware that they lack this knowledge and proceed accordingly, for example by pleading a Doe. Plaintiffs who know that they do not know the name of the correct defendant should not be im a worse position than plaintiffs who incorrectly name the wrong defendant, as in both siuations the effect of an amendment is to bring in a new party.

To summarize, when the correct defendant has been on notice both of the suit itself and that it is an intended defendant, denying relation back for amendments adding defendants or substituting named defendants for Doe defendants contravenes the federal rules' goal of facilitating decisions on the merits. In addition, in most such cases, denying relation back seems contrary to the philosophy behind Rule 15(c), as evidenced by the 1966 amendment and the Advisory Committee Note. ${ }^{184}$

\section{B. Expanding Relation Back Would Not Alter the Results in Most Rule 15(c) Cases}

Looking at relation-back cases, both those that allow relation back and those that do not, it becomes apparent that courts considering motions to ainend after the statute of limitations has passed place more weight on notice than on mistake. In many of the cases in which relation back is denied on the grounds that the mistake clause is not satisfied, the same result could be reached because of the absence of notice alone. For example, in Barrow v. Wethersfield Police Department ${ }^{185}$ the Second Circuit endorsed a strict interpretation of the mistake clause, forbidding relation back for amend-

184. See supra notes $172-174$ and accompanying text.

185. 66 F.3d 466 (2d Cir. 1995), as modified by 74 F.3d 1366 (2d Cir. 1996). 
ments substituting named defendants for Doe defendants. ${ }^{186}$ Although the court's analysis focused on the mistake clause, ${ }^{187}$ in its statement of facts the court noted that neither the intended defendants nor their attorneys were served with the complaint until well after the statute of limitations had passed. ${ }^{188}$ The court quoted the district court's order denying leave to amend, which stated that the plaintiff "had 'made no showing that the ... defendants had even constructive knowledge of the claims agamst them within 120 days of the court's receipt of the initial complaint."'189 Thus, even if it allowed relation back for amendments substituting named defendants for Doe defendants under Rule 15(c)'s mistake clause, the court would have reached the same result in the case because Rule 15(c)'s notice requirements were not satisfied. ${ }^{190}$

A year after Barrow, a district court within the Second Circuit considered another Doe substitution in Byrd v. Abate, ${ }^{191}$ which involved a civil rights claim against correctional facility officers. The court allowed relation back. ${ }^{192}$ Although Barrow held that Doe substitutions did not constitute mistakes, ${ }^{193}$ the Byrd court nonetheless allowed a Doe substitution, explicitly distinguishing Barrow on the grounds that the new defendants in Byrd were on notice and the plaintiff had pursued his claim diligently and in good faith. ${ }^{194}$ Thus, although Byrd conflicts with Barrow to a certain extent, the decisions are perfectly consistent with each other if considered on grounds of notice alone.

Furthermore, the minority of courts that interpret "mistake" broadly and already allow relation back for new defendants or Doe substitutions under the current language of the Rule emphasize the importance of notice to their decisions. In Varlack v. SWC Caribbean, Inc., ${ }^{195}$ for example, the

186. See id. at $469-70$ (denying relation back for a civil rights plaintiff in a police brutality suit who sought to substitute named, individual officers for Doe defendants).

187. See id.

188. Id. at 467 .

189. Id.

190. See also Wilson v. United States Gov't, 23 F.3d 559, 562-63 (1st Cir. 1994) (disallowing relation back for an amendment adding the United States as a party to a tort claim originally brought by an employee against his employer both because the United States had not received notice and because adding a party does not constitute a mistake); Frazier v. City of Philadelphia, 927 F. Supp. 881, 885 (E.D. Pa. 1996) (denying relation back for an amendment substituting named police officers as defendants in place of Doe defendants because, as the complaint did not state any underlying facts or even the date of the incident at issue, the officers could not have had notice); Perri v. Daggy, 776 F. Supp. 1345, 1349-50 (N.D. Ind. 1991) (denying relation back for an amendment substituting a named defendant for a Doe because of lack of notice even though the Seventh Circuit holds that Doe plcadings do not constitute mistakes).

191. 964 F. Supp. 140 (S.D.N.Y. 1997).

192. Id. at $144-46$.

193. Barrow, 66 F.3d at 469.

194. Byrd, 964 F. Supp. at 145-46.

195. 550 F.2d 171 (3d Cir. 1977). 
Third Circuit allowed relation back for a Doe substitution. ${ }^{196}$ Without analyzing the mistake clause separately, the court concluded that 15(c)(3) was satisfied when the intended defendant admitted that he had actual knowledge of the suit and knew that he was the "Unknown Employee" referenced in the complaint. ${ }^{197}$

In sum, the results of many of the cases which define and interpret Rule 15(c)(3)'s mistake clause can actually be explained solely by reference to the Rule's notice requirements. Therefore, expanding the availability of relation back while preserving the notice requirements is consistent with the philosophy underlying most of the cases that address relation back in these situations. Even though allowing relation back more broadly will conflict with the stated reasoning of several court cases, as long as the notice requirement is maintained, expanded relation back will correspond with and continue the reasoning underlying nost cases' actual results.

\section{Denying Relation Back Rewards Intended Defendants Who Obfuscate}

Denying relation back for amendments that add a defendant or substitute a named defendant for a Doe rewards defendants who obfuscate in order to prevent plaintiffs from determining their identity. This kind of defense tactic, whether intentional or inadvertent, occurs on occasion in civil rights claims brought against police or correctional officers. ${ }^{193}$ In most other kinds of lawsuits, the plaintiff has alternative means of finding out the defendant's true identity. For example, in suits against corporate defendants, readily available databases and public records contain relevant listings. ${ }^{199}$ In contrast, in suits against police or correctional officers, a plaintiff's ability to name the correct defendant is dependent upon the police or correctional department's willingness to comply with discovery requests and supply the officer's name. ${ }^{200}$

The case of Byrd v. Abate ${ }^{201}$ serves as a vivid example of dilatory behavior by intended defendants. Inmate Byrd brought a civil rights action against the Commissioner of the New York City Department of Corrections, the Mayor of New York, and John Doe, a correctional offi-

196. Id. at 174-75.

197. Id.; see also Henderson v. Hackel, 170 F.R.D. 430, 434 (E.D. Mich. 1997); Ortiz v. Betancourt Lebron, 146 F.R.D. 34, 40-42 (D.P.R. 1992).

198. E.g., Byrd, 964 F. Supp. at 142-43.

199. See Sterling v. Interlake Indus. Inc., 154 F.R.D. 579, 586 (E.D.N.Y. 1994) (taking judicial notice that a plaintiff who had sued the wrong corporate entity could have found out the correct defendant through "a five minute exercise on the NEXIS database, or a review of Standard \& Poor's Corporate Descriptions"). Even in civil cases between private litigants, however, it is possible for defendants' dilatory behavior to prevent the plaintiff from finding out the names of the desired defendants. E.g., Brink v. First Credit Res., 57 F. Supp. 2d 848, 857 (D. Ariz. 1999).

200. See Byrd, 964 F. Supp. at 146.

201. 964 F. Supp. 140 (S.D.N.Y. 1997). 
cer. ${ }^{202}$ Byrd's counsel first verbally asked the defendants' counsel for disclosure of the unknown officer's identity in January 1994. ${ }^{203}$ The defendants' counsel replied that he was "unaware of the officer's name."204 Byrd's counsel then sought discovery of the correctional facility's log books. ${ }^{205}$ The defendants wanted to bifurcate Byrd's claims against the Commissioner and Mayor from his claim against the John Doe officer, and they refused to turn over the log books until Byrd agreed to the bifurcation or the court ruled on a bifurcation motion. ${ }^{206}$ The court issued a bifurcation order, but the defendants still did not supply the officer's name or produce the log books. ${ }^{207}$

On October 4, 1994, the applicable statute of limitations expired ${ }^{208}$ In November of 1994, Byrd's counsel served the defendants with a notice of deposition "for the 'John Doe' Correction Officer to be held on December 6, 1994."209 For reasons not stated in the court's opinion, the deposition did not take place. ${ }^{210}$ On January 3, 1995, Byrd's counsel again asked the defendants to identify the officer and schedule a deposition. ${ }^{211}$ The defendants finally told Byrd that the John Doe officer's name was Wade Hults on January 12, 1995, a year after Byrd's first request ${ }^{212}$ and three months after the statute of limitations had run. ${ }^{213}$ Byrd served an amended complaint on February $27,1995 .{ }^{214}$ Hults answered the complaint in March, 1995, but did not assert a statute of limitations defense. ${ }^{215}$ A year and a half later, while their summary judgment motion was pending, the defendants sought leave to amend Hults's answer to assert a statute of limitations defense. ${ }^{216}$ They also requested a stay of discovery until the court decided whether to allow the amendment. ${ }^{217}$ Holding that the amended complaint related back, the district court denied Hults's request. $^{218}$ Other cases contain similar examples of obfuscatory behavior. ${ }^{219}$

202. Id, at 143 .

203. Id.

204. Id.

205. Id.

206. Id.

207. Id.

208. Id. at 144 .

209. Id. at 143 .

210. See id.

211. Id.

212. Id.

213. Id. at 142 .

214. Id. at 143.

215. Id.

216. Id. at 142 .

217. Id.

218. Id. at 147.

219. E.g., King v. One Unknown Fed. Corr. Officer, 201 F.3d 910, 912-13 (7th Cir. 2000); Donald v. Cook County Sheriff's Dep't, 95 F.3d 548, 551-53, 558 (7th Cir. 1996) (describing incarcerated pro 
Faced with such dilatory behavior on the part of an intended defendant, a plaintiff whose amendment is denied relation back also will be denied a hearing on the merits of her claim through no fault of her own. To escape defendimg on the merits, a police or correctional officer need only ensure that the government counsel defending her puts off or fights discovery requests until the statute of limitations has passed. ${ }^{220}$ Although the statute of limitations is meant to protect defendants by providing them with repose after a certain period has passed, ${ }^{221}$ it should not protect a defendant who has notice of suit within the applicable limitations period, but none-

se civil rights plaintiff's efforts to amend his complaint to name individual officers and noting that the plaintiff's "diligence [was] particularly striking in light of the dilatory tactics of the defendants... The defect in [the plaintiff's] choice of defendants ... must have been immediately apparent both to the defendant and to the district court. In spite of this, the district court [sua sponte] gave the Department four-and-a-half months-rather than twenty days-to respond to the complaint"); Cunningham v. Eyman, 11 F. Supp. 2d 969, 973-75 (N.D. 111. 1998). In King, the plaintiff, an incarcerated federal prisoner initially proceeding pro se, alleged that a correctional officer failed to prevent an attack on the plaintiff by other inmates or heed the plaintiff's cries for help during the attack. King, 201 F.3d at 912. In October 1994, two months before the expiration of the statute of limitations, the plaintiff filed suit against "One Unknown Federal Correctional Officer." Id. He further identified the officer as being the one who allowed one of the inmates who attacked the plaintiff to enter from another ward without checking him for weapons. Id.

Prior to filing suit, the plaintiff had already attempted to find out the officer's identity through several Freedom of Information Act ("FOIA") requests, including one in April 1993, over a year and a half before the expiration of the statute of limitations. Apparently this April 1993 request was the only one that received any response other than a rejection, but this response did not enable the plaintiff to determine the correct defendant's name. According to the Seventh Circuit's opinion, in response to the April 1993 request, "the BOP [Bureau of Prisons] identified 37 pages of relevant records. But, citing the sensitive nature of those records, [it] released only seven pages to [the plaintiff]." Id. at $912 \mathrm{n} .3$. In December 1995 the plaintiff filed a motion for limited discovery. Id. at 912 . The district court denied this request on the grounds that the Bureau of Prisons records contained sensitive information. In January, 1996, the plaintiff filed a motion for production of the work roster for the correctional officers on the day he was attacked. The district court denied this motion on the same grounds.

On its own motion, the district court then decided that it would review the relevant prison records in camera to determine the correct officer's identity. After such a review, the district court determined that the correct officer was Lieutenant T. Huckleberry. The plaintiff, however, immediately wrote a letter to the court explaining that Huckleberry was not the correct defendant. In January 1997 the case was transferred to a new judge. In October 1997, the plaintiff obtained counsel. The district court allowed counsel to enter a limited appearance and issued a proposed order that would have allowed the plaintiff's counsel to review the relevant prison records to determine the correct officer's identity. A few months later, the district court reversed this position and performed another in camera review, this time determining that the correct defendant was Correctional Officer L. Suttler. However, as with Huckleberry, the plaintiff notified the court that Suttler was not the proper defendant. In addition, counsel notified the court that he would not be representing the plaintiff.

In June 1998 the district court appointed counsel for the plaintiff and issued a proposed order that would have allowed this new counsel to inspect the relevant prison records. Again, the BOP objected to this order. Without ruling on the BOP's objection, the court issued an Order to Show Cause why the action should not be dismissed as time-barred. The plaintiff responded, but to no avail, and in November 1998 the court dismissed the action with prejudice.

220. Byrd, 946 F. Supp at 146 ("To hold that Rule 15(c) does not permit relation back in such circumstances would permit defense counsel to eliminate claims against any John Doe defendant merely by resisting discovery requests until the statute of limitations has ended.").

22I. See Shapiro, supra note 40 , at 672 \& nn.6-9. 
theless purposefully manipulates the situation so as to be able to use the statute of limitations as a procedural weapon. ${ }^{222}$

\section{Expanding Relation Back Would Not Decrease the Diligence Required of Plaintiffs}

One could argue that granting plaintiffs more leeway to amend will discourage diligent investigation of claims and case preparation. However, other provisions of Rule 15 and the general standards that guide courts' discretion when considering motions for leave to amend would enable a court to deny relation back when plaintiffs have not acted diligently.

At first glance, it seems logical to assume that allowing relation back more broadly would encourage plaintiffs to put off bringing in all potential defendants. Knowing that a later amendment to substitute named defendants for Doe defendants or to add new defendants has the potential to relate back might lead more plaintiffs to file suit before doing thorough research to ascertain all possible defendants. Similarly, perhaps the availability of relation back for future amendments would encourage plaintiffs to relax their efforts to identify unnamed defendants once an action has been instituted. Finally, plaintiffs who know that an amendment would relate back might be tempted to delay naming a defendant in order to "ambush" that defendant right before trial when there is little time to prepare a defense.

Existing provisions of Rule 15, independent of the mistake requirement, suggest that such results are unlikely. The notice provisions of $15(c)(3)$ require that defendants brought in by amendment both be on notice of the action itself and be on notice that the plaintiff intended to sue then1. ${ }^{223}$ Plaintiffs who do not pursue their claims vigorously run the risk of failing to satisfy these tests, as intended defendants usually are placed on

222. Equitable tolling of the statute of limitations, available under the current rules, is another potential solution to the problem of dilatory defendants. E.g., Friedman v. Campbell, No. 98-6728, 1999 WL 1045281, at *2 (6th Cir. Nov. 8, 1999) (unpublished decision) (directing district court, on remand, to consider tolling if it found that an amendment proposed after the statute of limitations had run did not relate back); Donald v. Cook County Sheriff's Dep't, 95 F.3d 548, 561-62 (7th Cir. 1996) (remanding case for determination of whether defendants sought to be brought in by amendment after the statute of limitations had run had notice of the suit and that they were intended defendants; stating that if notice was lacking, the district court should consider whether to toll the statute of limitations); Cunningham v. Eyman, 11 F. Supp. 2d 969 (N.D. Ill. 1998) (tolling the statute of limitations and ordering a federal law enforcement agency to provide the names of individual officers involved in the actions of which the plaintiff complained).

Equitable tolling would not be a solution in all cases, however, because courts apply it rarely and, before doing so, require a very strong showing that the plaintiff was unable to sue before the expiration of the statute of limitations "despite all reasonable diligence." Donald, 95 F.3d at 562 (quoting Singletary v. Continental Illinois Nat'l Bank \& Trust Co., 9 F.3d 1236, I241 (7th Cir. 1993)); see also Wilson v. United States Gov't, 23 F.3d 559, 561 (1st Cir. 1994) ("Federal courts have allowed equitable tolling only sparingly.").

223. FED. R. CIV. P. 15(c)(3)(A)-(B). 
notice by the plaintiff's actions regarding the litigation or attempts at discovery. Several of the courts that currently allow amendinents adding defendants or substituting for Doe defendants draw a "distinction . . . between the plaintiffs' strategy or lack of due diligence and their honest error," only allowing relation back for the latter because otherwise the defendant would not be on notice. ${ }^{224}$

In addition, the generally applicable standards that guide courts' discretion in considering motions for leave to amend would enable a court to deny a request made in situations such as those described above. A court may deny any motion for leave to amend when it finds that the movant has acted in bad faith or with dilatory motive. ${ }^{225}$ This rule is a judicial gloss on Rule 15(a)'s requirement that leave to amend "shall be freely given when justice so requires." 226 Pursuant to this rule, a trial court faced with a motion for leave to annend to name a defendant after the statute of limitations has run must analyze the situation to determine whether the plaintiff purposefully delayed or failed to pursue the developinent of the case diligently. If so, the court may deny leave to amend. In addition, a court may deny leave to amend when allowing the amendinent would prejudice the defendant's ability to prepare a defense. ${ }^{227}$ Therefore, when allowing an amendment to relate back would prejudice the defendant, a court could deny it. ${ }^{228}$

Thus, allowing relation back more liberally than the majority of courts currently do would not dramatically decrease the diligence required of plaintiffs. The notice requirements of Rule 15(c)(3) and the standards applicable to all motions for leave to amend ${ }^{229}$ would enable courts to deny relation back when plaintiffs delay unduly or act in bad faith, or when the amendinent comes so late that it would prejudice the defendant.

224. In re Integrated Res. Real Estate Ltd. P'ships Sec. Litig., 815 F. Supp. 620, 644 (S.D.N.X. 1993); see also Advanced Power Sys., Inc. v. Hi-Tech Sys., Inc., 801 F. Supp. 1450, 1457 (E.D. Pa. 1992) (stating that relation back is proper only when the new party is "aware[] that failure to join it was error rather than a deliberate strategy").

225. See Foman v. Davis, 37I U.S. 178, 182 (1962) (holding that a trial court may deny a motion to amend if it finds "undue delay, bad faith, or dilatory motive on the part of the movant").

226. FED. R. CIV. P. 15(a).

227. See Foman, 371 U.S. at 182.

228. E.g., Wine v. EMSA Ltd. P'ship, 167 F.R.D. 34, $39-40$ (E.D. Pa. 1996) (holding that relation back would be allowed for an amendment bringing in new defendants but nonetheless denying leave to amend on the grounds, applicable to any motion for leave to amend, that the plaintiff had delayed unduly in seeking leave to amend); see also Pembroke v. City of San Rafael, No. C 921869 BAC, 1994 WL 443683, at $\div 2$ (N.D. Cal. Aug. 2, 1994) (unpublished decision) (denying relation back for an amendment that added individual police officers as defendants in a civil rights suit on the grounds that the mistake condition was not satisfied by lack of knowledge but also on the alternative grounds that the amendment should be denied because of undue delay and prejudice, considered under the general standards for all motions for leave to amend).

229. See supra notes 225-227 and accompanying text. 
IV

\section{Rule 15(c) Should Be Amended to Allow Relation Back}

Part III has argued that relation back should be allowed in cases of misnomer, mistaken identity, additions and Doe substitutions, as long as the new defendant has been on notice both of the action and that it is an intended defendant. The next question is how this result can be achieved. Although a minority of courts hold that the current language of Rule 15(c) can be interpreted broadly enough to allow amendments after the statute of limitations has run in these situations, the majority of courts do not. Allowing relation back in these situations contradicts the common understanding of the word "mistake" and leaves open the possibility of inconsistent results. Thus, judicial re-interpretation of the mistake clause is neither a likely nor an adequate solution to this problem. Therefore, Rule 15(c) should be amended to explicitly allow relation back when the plaintiff lacked knowledge of the identity of the proper defendant and when this lack of knowledge causes the plaintiff's failure to bring in the defendant prior to the expiration of the statute of limitations.

\section{A. Judicial Re-Interpretation of Rule 15(c) Is Not an Adequate Solution}

A minority of courts allow relation back in the situations described above on the grounds that the plaintiff has made a "mistake" within the meaning of Rule 15(c). For example, the court in Williams v. Avis Transport of Canada, Ltd. stated that a mistake "exists whenever a party who may be liable for the actionable conduct alleged in the Complaint was omitted as a party defendant." ${ }^{230}$ Some commentators have argued that relation back should be allowed at least in Doe situations under the current language of the Rule. ${ }^{231}$ However, this approach is inadequate for two reasons. First, calling a lack of knowledge a "mistake" does not comport with the common understanding of what the word "mistake" means. Second, this approach would not give courts or litigants clear guidance as to when relation back should be allowed.

\section{Doe Defendants Are Not Left Unnamed by "Mistake"}

Although arguing that plaintiffs in some of the situations identified above ${ }^{232}$ have made "mistakes" is plausible, such an argument would not cover amendments to add new parties or substitute named defendants for

230. 57 F.R.D. 53, 55 (D. Nev. 1972).

231. See Sparling, supra note 29, at 1239 (arguing that pleading a Doe constitutes a "mistake" under the Rule). While not arguing that a Doe pleading constitutes a mistake, Professor Rice argues for a solution to the relation back problem that only addresses Doe situations. See Rice, supra note 98, at 884-85. She suggests that federal procedure should explicitly incorporate Doe practice through a new rule that would provide standards to govern pleading, diversity jurisdiction and venue, and relation back for Doe parties. See id. at 946-58.

232. See supra Part I1. 
Does. Therefore, interpreting the language of the Rule broadly is unsatisfactory as a means of broadening the application of relation back.

People make mistakes when they "misunderstand[] ... the meaning or implication of something."233 Courts agree that plaintiffs in "misnomer" cases have made a mistake, both im terms of the common understanding of the word and within the meaning of Rule 15(c) ${ }^{234}$ Although a few courts disagree that a plaintiff im a mistaken identity situation, who thought that $A$ is the legally responsible entity when actually $B$ is, can be said to have made a mistake within the meaning of the Rule, ${ }^{235}$ in terms of common usage it is plausible to say that such plaintiffs are mistaken. Such plaintiffs misunderstand $A$, the relationship of $A$ to the events that underlie the action, and the relationship of $A$ to the plaintiff.

However, no one casually discussing a plaintiff who had filed a complaint against a Doe defendant would say that the plaintiff had made a "mistake." Such plaintiffs do not misunderstand either who the Doe is or the relationship between the Doe and themselves. Instead, plaintiffs suing Doe defendants are fully aware that they lack knowledge of the identity of the party they intend to sue, and that awareness prompts them to include a Doe defendant. ${ }^{236}$ For this reason, judicially re-interpreting the language of Rule 15(c) to include Doe pleadings is contradictory and unsatisfying.

\section{Broad Judicial Re-Interpretation of "Mistake" Would Still Allow for Inconsistent Results and Would Not Give Litigants Clear Guidance}

Even if the majority of courts changed their interpretation of Rule 15(c)'s mistake clause and uniformly endorsed a broader approach to relation back, the current language of Rule 15(c) would still allow for inconsistent results and fail to give litigants clear guidance. Some of the courts that currently allow relation back for amendments making Doe substitutions or adding new defendants interpret the mistake clause so broadly that it subsunies the notice requirement. ${ }^{237}$ In Taliferro $v$. Costello, ${ }^{238}$ the district court allowed the plaintiffs in a $\S 1983$ police brutality case to amend their complaint, originally brought against the deputy sheriff, to add the City of Philadelphia as a defendant. ${ }^{239} \mathrm{~A}$ better result in this case would have been to deny anendment on the grounds that the City of Philadelphia could not have had notice that it was intended to be a defendant, as the plaintiffs could have omitted it for strategic reasons. ${ }^{240}$

233. Webster's Third New InTERnational Dictionary 1446 (1986).

234. See supra Part II.A.

235. See supra Part li.B.

236. Cf. WeBSTER's, supra note 233 , at 1446 (stating that an "unintentional error" is a mistake).

237. See Rice, supra note 98 , at 933-37.

238. 467 F. Supp. 33 (E.D. Pa. 1979).

239. Id. at 36 .

240. See Rice, supra note 98 , at 935-36. 
Without an explicit amendment clarifying the Rule's relation-back provisions, courts could continue to interpret the clause more or less narrowly.

\section{B. A Proposed Amendment to Rule 15(c)}

Rule 15(c) should be amended to explicitly allow relation back when a plaintiff seeks to add a new defendant or substitute a named defendant for a Doe. This clarification could be accomplished through the addition of the phrase "the movant's lack of knowledge of the proper party, or" to 15(c)(3)'s last sentence. So amended, subsection (3) of the Rule would read:

(3) the amendment changes the party or the naming of the party against whom a claim is asserted if the foregoing provision (2) is satisfied and, within the period provided by Rule 4(m) for service of the summons and complaint, the party to be brought in by amendment (A) has received such notice of the institution of the action that the party will not be prejudiced in maintaining a defense on the merits, and (B) knew or should have known that, but for the movant's lack of knowledge of the proper party, or a mistake concerning the identity of the proper party, the action would have been brought against the party. ${ }^{241}$

This amendment would allow relation back both when a plaintiff seeks to add a new defendant because of a mistake regarding the characteristics of the original defendant, as in Wilson v. United States Government, ${ }^{242}$ and when the plaintiff seeks to substitute a named defendant for a Doe, as in Wood v. Worachek. ${ }^{243}$ By not eliminating the notice requirements, it does not circumvent the policy behind the statute of limitations and does not leave defendants without protection from late or surprising claims. Although this amendment would reverse the outcome of some of the cases cited above, it would not reverse the result in all, and it would only do so when the mistake is being used as a technicality. For example, relation back should still be denied when the proposed defendant lacks notice either of the suit or that it was an intended defendant. In addition, relation back should be denied when the plaintiff knows the proposed defendant's identity and is not mistaken about the need to sue that defendant. ${ }^{244}$

24I. FED. R. CIV. P. 15(c)(3) (emphasis indicates suggested additional text).

242. 23 F.3d 1498 (9th Cir. 1994).

243. 618 F.2d 1225 (7th Cir. 1980).

244. See, e.g., Lembach v. State of Indiana, 987 F. Supp. 1095, 1099 \& n.4, 1101 (N.D. Ind. 1997). In Lembach, the district court denied relation back for an amendment naming individual correctional officers as defendants in a $\$ 1983$ action originally brought only against state defendants. The result would be the same under a Rule 15 (c) revised as proposed because the plaintiff had knowledge of the new defendants' identities at the time of filing. The piaintiff had included one individual officer's name on a notice of claim filed with the state well in advance of the date he had filed his lawsuit. Id. at $1100 \mathrm{n} .4$. The other individual defendant was the superintendent of the prison in 
Looking at all the cases, it becomes apparent that the determinative factors are notice and whether the plaimtiff had an earlier opportunity to amend. When it seems likely that the plaintiff knew the additional defendant existed but failed to name it either through carelessness or because of poor legal advice, courts are likely to deny relation back. ${ }^{245}$ In contrast, courts are much more likely to allow relation back when it seems probable that the plaintiff truly did not know that the additional defendant existed or, in a Doe situation, had no means of determining the Doe's identity, and then amended as soon as possible after learning the new defendant's identity. Courts attempt to fit this reasoning into a determination of whether or not the Rule's mistake clause is satisfied, but this kind of analysis actually seems to be looking at different considerations altogether: notice to the new defendant and whether the plaintiff has acted carelessly or in bad faith. If an mitially unaware plamtiff learns the identity of a potential defendant but fails to bring that party in, the potential defendant is justified in thinking that the plaintiff has omitted it for strategic reasons. Similarly, if a plaintiff is aware at the outset of litigation that an entity exists but does not realize that entity is a potential defendant that should be named, that defendant also is justified im thinking that it has not been named for strategic or tactical reasons. Such situations are different from common $\S 1983$ situations, for example, where the individual defendants are represented by the same government counsel that represents a municipal defendant and have even been imterviewed or given statements about the events underlying the litigation.

which the plaintiff was incarcerated, a person whose name most prisoners know. Id. In addition, this plaintiff made no mistake of law because the original state defendants' motion to dismiss put him on notice that he needed to sue the individual defendants, yet he did not immediately seek leave to amend his complaint to name them. $I d$. at 1100 .

Similarly, the proposed additional language for the Rule would not change the result in In re Brand Nane Prescription Drugs Antitrust Litigation, No. 94 C 897, MDL 997, 1998 WL 474146 (N.D. Ill. Aug. 6,1998$)$. In this case, the plaimtiffs originally named several entities not as defendants, but as coconspirators in the body of their complaint. Id. at *1. Later, the plaintiffs sought to amend their complaint to name these individuals as defendants. Id. The court denied relation back on the grounds that the plaintiffs had knowledge of the individuals' identities, evidenced by the fact that the plaintiffs named the individuals in the body of their complaint, and did not misunderstand the individuals' legal capacities. Id. at $* 3$ ("Nor is there any question that the Individual Plaintiffs knew full well who the Wholesalers were and deliberately chose not to name thein as defendants in their original complaints."); see also id. at "5. As these plaintiffs did not "lack ... knowledge" of a proper defendant, their proposed amendment would not relate back under this Comment's proposed amendment to Rule 15(c).

245. For example, in Bloesser v. Office Depot, Inc., 158 F.R.D. 168, 171 (D. Kan. 1994), a slip and fall case, the district court denied relation back for an amendinent seeking to substitute a specific, named construction company for a Doe construction company. Suggesting that it would have allowed relation back had the plaintiff either been unable to determine the company's name through due diligence or had been unaware of its potential liability for suit, the court stated that "excusable neglect by plaintiff is relevant to determining whether plaintiff's mistake was merely tactical or a true mistake in identity.... Because plaintiff could have discovered the identity of [the correct defendant company] before the limitations period had expired, his failure to do so is not excusable neglect and represents a tactical mistake instead of a true mistake in identity." Id. at 171. 
The issues of notice and diligence are important, perhaps crucial, and can still be taken into account under the proposed modification of the Rule. For an amendment to relate back, the new defendant still must have had notice both of the institution of the action and its status as a potential defendant. In addition, when the plaintiff does not amend promptly after learning of the new party's identity, the court can deny leave to amend under the Foman factors of undue delay and bad faith. ${ }^{246}$

\section{CONCLUSION}

As numerous courts and commentators have stated, one of the primary purposes of the Federal Rules of Civil Procedure is to facilitate adjudication of claims on the merits, rather than on technicalities. Relation-back doctrine creates an exception to the normal bar imposed by statutes of limitations precisely to achieve this end. Although Federal Rule of Civil Procedure 15 has been amended twice since its adoption to broaden the availability of relation back and clarify when the doctrine should be applied, the Rule still allows for inconsistent results in two kinds of situations: when the plaintiff seeks to add a new defendant that it could not have known about at the beginning of the suit, and when the plaintiff seeks to substitute a named defendant for a Doe.

So long as its notice requirements are kept intact, the Rule should be amended so that it will clearly allow relation back in these situations. Rule 15 's notice requirements protect defendants from the same dangers as do statutes of limitations, and courts' discretion to deny leave will ensure good faith and timely prosecution of claims by plaintiffs. Thus, by explicitly allowing relation back for amendments adding new defendants and substituting named defendants for Does, an amended Rule 15 would better comport with the goals of both the federal rules in general, and Rule 15(c) in particular.

246. See supra note 225 and accompanying text. 